\title{
A Putative Lignin Copper Oxidase from Trichoderma reesei
}

\author{
Mariane Daou ${ }^{1,+}{ }^{\dagger}$, Alexandra Bisotto ${ }^{1}$, Mireille Haon ${ }^{1}$, Lydie Oliveira Correia ${ }^{2} \mathbb{D}$, Betty Cottyn ${ }^{3}$, Elodie Drula ${ }^{1}$, \\ Soňa Garajová ${ }^{1}$, Emmanuel Bertrand ${ }^{1}{ }^{\oplus}$, Eric Record ${ }^{1}{ }^{10}$, David Navarro ${ }^{1,4}$, Sana Raouche ${ }^{1}{ }^{\mathbb{D}}$, \\ Stéphanie Baumberger ${ }^{3}$ and Craig B. Faulds ${ }^{1, *(1)}$
}

1 BBF, INRAE, Aix Marseille University, 13288 Marseille, France; mariane.daou@ku.ac.ae (M.D.); alexandra.bisotto@gmail.com (A.B.); mireille.haon@inrae.fr (M.H.); elodie.drula@inrae.fr (E.D.); sona.garajova@univ-amu.fr (S.G.); emmanuel.bertrand@univ-amu.fr (E.B.); eric.record@inrae.fr (E.R.); david.navarro@inrae.fr (D.N.); sana.raouche@univ-amu.fr (S.R.)

2 PAPPSO Platform, INRAE, AgroParisTech, Micalis Institute, Université Paris-Saclay, 78350 Jouy-en-Josas, France; lydie.oliveira-correia@inrae.fr

3 Institut Jean-Pierre Bourgin, INRAE, AgroParisTech, Université Paris-Saclay, 78000 Versailles, France; betty.cottyn@inrae.fr (B.C.); stephanie.baumberger@inrae.fr (S.B.)

4 CIRM-CF BBF, INRAE, Aix Marseille University, 13288 Marseille, France

* Correspondence: craig.faulds@univ-amu.fr

+ Current address: Department of Biology, Khalifa University of Science and Technology, Abu Dhabi 127788, United Arab Emirates.

\section{Citation: Daou, M.; Bisotto, A.;} Haon, M.; Oliveira Correia, L.; Cottyn, B.; Drula, E.; Garajová, S.; Bertrand, E.; Record, E.; Navarro, D.; et al. A Putative Lignin Copper Oxidase from Trichoderma reesei. J. Fungi 2021, 7, 643. https://doi.org/ $10.3390 /$ jof7080643

Academic Editor: Laurent Dufossé

Received: 8 July 2021

Accepted: 5 August 2021

Published: 7 August 2021

Publisher's Note: MDPI stays neutral with regard to jurisdictional claims in published maps and institutional affiliations.

Copyright: (c) 2021 by the authors. Licensee MDPI, Basel, Switzerland. This article is an open access article distributed under the terms and conditions of the Creative Commons Attribution (CC BY) license (https:/ / creativecommons.org/licenses/by/ $4.0 /)$.
Abstract: The ability of Trichoderma reesei, a fungus widely used for the commercial production of hemicellulases and cellulases, to grow and modify technical soda lignin was investigated. By quantifying fungal genomic DNA, T. reesei showed growth and sporulation in solid and liquid cultures containing lignin alone. The analysis of released soluble lignin and residual insoluble lignin was indicative of enzymatic oxidative conversion of phenolic lignin side chains and the modification of lignin structure by cleaving the $\beta-\mathrm{O}-4$ linkages. The results also showed that polymerization reactions were taking place. A proteomic analysis conducted to investigate secreted proteins at days 3,7 , and 14 of growth revealed the presence of five auxiliary activity (AA) enzymes in the secretome: AA6, AA9, two AA3 enzymes), and the only copper radical oxidase encoded in the genome of $T$. reesei. This enzyme was heterologously produced and characterized, and its activity on lignin-derived molecules was investigated. Phylogenetic characterization demonstrated that this enzyme belonged to the AA5_1 family, which includes characterized glyoxal oxidases. However, the enzyme displayed overlapping physicochemical and catalytic properties across the AA5 family. The enzyme was remarkably stable at high $\mathrm{pH}$ and oxidized both, alcohols and aldehydes with preference to the alcohol group. It was also active on lignin-derived phenolic molecules as well as simple carbohydrates. HPSEC and LC-MS analyses on the reactions of the produced protein on lignin dimers (SS $\beta \beta$, SS $\beta \mathrm{O} 4$ and GG $\beta 5$ ) uncovered the polymerizing activity of this enzyme, which was accordingly named lignin copper oxidase ( $\operatorname{Tr} \mathrm{LOx})$. Polymers of up 10 units were formed by hydroxy group oxidation and radical formation. The activations of lignin molecules by TrLOx along with the co-secretion of this enzyme with reductases and FAD flavoproteins oxidoreductases during growth on lignin suggest a synergistic mechanism for lignin breakdown.

Keywords: Trichoderma reesei; technical lignin; copper radical oxidase

\section{Introduction}

Agaricomycetes have been long studied for their ability to mineralize woody biomass. A number of representative white-rot fungi belonging to the Basidiomycetes, such as Phanerochaete chrysosporium, Trametes versicolor, and Pleurotus ostreatus, have in particular been analyzed because of their effectiveness in converting lignocellulosic material into $\mathrm{CO}_{2}$, primarily due to the enzymes (see [1], 2015, and references therein) and small organic molecules that they secrete during growth on such biomass. There is continual interest in 
obtaining fermentable sugars [2-4], high value animal feed [5], and high value chemical precursors to replace fossil-fuel-derived compounds through environmental processes, and the initiative towards zero waste within a circular bioeconomy framework [6]. This continues to drive towards understanding further how secreted microbial enzymes interact with their substrates and each other, and what factors prevent or enhance such interactions.

The impact of the connectivity of the individual components within woody and nonwoody lignocellulosic feedstocks on their biodegradability has to be understood, and the use of proteomic, transcriptomic and secretomic tools to understand the microbial enzymatic mechanisms is greatly expanding this knowledge [7-9]. Many recently published works have concentrated on these-Omic approaches coupled with biochemical and microbiological analysis for the fungal degradation of the lignocellulosic components from divergent plant sources $[7,8,10-14]$. The arsenal of enzymes that these fungi secrete at different time points of growth are still largely unknown, but their presence leads to an empirical improved boost in saccharification for the production of biofuels or the release of small molecules of interest for further bioconversion. Changes to the composition of the biomass have facilitated the study of enzyme synergies and approaches for determining the systematic order of biomass deconstruction, and especially the untangling of the lignin component from the polysaccharides [15]. However, due to the recalcitrant nature of the lignin component, coupled with obtaining a well-characterized native lignin through chemical extraction, less is known about how fungi specifically degrade lignin, either native or technical from industrial processes, compared to that from the more composite lignocellulose.

Investigations into a successive degradation pattern of wood colonization by fungi have illustrated that the Basidiomycetes dominate the initial stages of deconstruction of the biomass, while Ascomycetes take over this role in the later stages [16,17]. Ascomycetes fungi are generally regarded as soft-rot degraders of various forms of plant biomass, and compared to the basidiomycetes, their ability to degrade lignin is considered as being limited $[18,19]$. Soft-rot fungi are found on a wide array of lignocellulosic substrates, such as herbaceous plant debris (wheat straw), whereas basidiomycetous decayers are usually restricted to wood [20]. One possibility suggested is that ascomycetes have a limited arsenal of lignin-attacking enzymes, and so are capable of attacking only the phenolic units in lignin which are chemically more labile than the remaining ether-linked, nonphenolic units $[20,21]$, which require action of stronger oxidants, such as the oxyradicals produced by ligninolytic peroxidases or laccases in the presence of various redox mediators. In 2007, Shary and co-workers demonstrated that the ascomycete Daldinia concentrica produced a phenol oxidase activity that could act directly on such phenol units, and proposed that this cleavage of the $C_{\alpha}-C_{\beta}$ propyl side chains was one of the major mechanisms of this fungus being able to degrade lignin [22]. Another suggestion for the production of these oxidases is the natural production of $\mathrm{H}_{2} \mathrm{O}_{2}$ to act as a bactericide in the environment [23]. The coprophilous ascomycete, Podospora anserina, more known for its ability to degrade carbohydrate, has been one ascomycete studied for its ligninolytic activities due to its ease of culture and genetic analysis. This fungus has been shown to produce laccases, which are involved in phenolic compound oxidation, although a role in actual lignin depolymerization was inconclusive [24], and a catalase capable of harnessing released hydrogen peroxide [25]. The fungus has also been shown to degrade lignin through the reduction of $\beta-\mathrm{O}-4^{\prime}$ aryl ether linkages, a linkage that represents more than $50 \%$ of all inter-unit linkages of native lignins (softwood: $45-50 \%$, hardwood: $60-80 \%$, grasses: 69-94\%) [26-28]. Previously, an extracellular $\beta$-etherase capable of cleaving this bond was isolated from an ascomycete of the genus Chaetomium [29]. Furthermore, the released phenolics further stimulated growth of $P$. anserina due to augmented radical oxygen species production [27].

As a component of the secreted enzymatic arsenal utilized by fungi, the copper radical oxidases (CRO, previously also known as radical-copper oxidases; [30]) have generally been regarded as an accessory enzyme in the ligninolysis process, generating $\mathrm{H}_{2} \mathrm{O}_{2}$ for the heavy cleavage action of peroxidases [31]. They have subsequently been found to require 
themselves the presence of a peroxidase or catalase in a two-fold mechanistic function: (1) to utilize the $\mathrm{H}_{2} \mathrm{O}_{2}$ produced during catalysis and thus avoid auto-inactivation, and (2) for full activation of the resting state of the CRO [32-34]. The genes encoding CROs are widely distributed in the Fungal Kingdom, and the copper-binding catalytic center is well preserved. Five CRO subfamilies have been recognized for Basidiomycetes $[35,36]$, all belonging to the AA5_1 family of the CAZy classification [37,38], and clearly separate from the galactose oxidase (GalOx) clades in AA5_2 [39], although recent studies are showing the existence of AA5-classified oxidase from the Ascomycete Penicillium rubens with a functional overlap between the two subfamilies [40]. Glyoxal oxidase (GLOX) has been the most extensively studied of the AA5_1 CROs to date [32,36,41], with their ability to utilize an array of aldehydes and $\alpha$-hydroxycarbonyls as the substrates converting them in sequential reactions to carboxylic acids $[35,36]$.

During the published study on three basidiomycetes grown on a technical soda lignin, Protobind 1000, a number of enzymes were identified in the secretomes specific to growth of the fungi on lignin alone, including CROs [42]. As part of the same study, the ascomycete Trichoderma reesei was also examined, initially as an outlier as it is known as a cellulolytic fungus rather than a lignocellulolytic one [43]. This paper describes the identification, cloning, heterologous expression of a CRO identified in the secretome, together with an investigation into its substrate specificity. The relation of this enzyme to the residual technical soda lignin after growth of $T$. reesei is also discussed.

\section{Materials and Methods}

\subsection{Fungal Strain}

Polyploid strain of the fungus Trichoderma reseei BRFM 1104 (QM6a) was obtained from the International Centre of Microbial Resources, Marseille, France (CIRM-CF; https: / / www.cirm-fungi.fr, accessed 7 August 2021). The identity of the strain was checked by morphological observations and molecular analysis of Internal Transcribed Spacer sequences compared to Genbank [44]. The strain was maintained on potato dextrose agar (Sigma-Aldrich, St. Louis, MO, USA) slants at $4{ }^{\circ} \mathrm{C}$.

\subsection{Growth on Lignin}

The soda technical lignin (Protobind 1000) used in this study was produced from a wheat straw and Sarkanda grass mix and purchased from GreenValue Enterprises LLC (Media, PA, USA). The sample was analyzed for Klason lignin (88.1\%), carbohydrates (1.9\%, of which $1.2 \%$ xylose, $0.3 \%$ arabinose, $0.1 \%$ galactose and $0.2 \%$ glucose), free phenolic monomers (1.4\%) and ash contents (1.4\%) [42].

From agar slants, T. reseei was transferred and grown on potato dextrose agar plates (Sigma-Aldrich, St. Louis, MO, USA). Cultures on minimal media plates containing $10 \mathrm{~g} / \mathrm{L}$ technical soda lignin and in submerged cultures containing $100 \mathrm{~mL}$ of lignin-containing media (10 g/L technical soda lignin) were performed as previously described [42]. Control conditions were supplemented with $1 \mathrm{~g} / \mathrm{L}$ glucose and $2.5 \mathrm{~g} / \mathrm{L}$ maltose for plate and liquid cultures, respectively. All cultures were performed in duplicate.

Fungal growth on plates was followed by measuring the radial expansion of the fungus (cm/day). Growth in liquid cultures was followed by quantifying the fungal DNA material and relating it to the mycelial dry weight as previously described [42,45].

Residual solid material from liquid cultures was harvested and used for the characterization of insoluble lignin. Concentrated supernatants were used for proteomic analysis. The flow through from the concentration step was also collected to analyze changes in the water-soluble components of technical soda lignin.

\subsection{Characterization of Residual Lignin}

Ten milliliters $(10 \mathrm{~mL})$ of culture supernatant from day 14 of growth and the control were used to analyze soluble lignin residues by High Pressure Size Exclusion chromatography method (HPSEC) (Dionex Ultimate 3000, Thermo Scientific, Saint Aubin, France) and 
liquid chromatography-mass spectrometry (LC-MS) (UHPLC, Thermo Scientific; Impact II, Bruker, Billerica, MA, USA), after extraction with ethyl acetate. The control consisted of the culture media containing lignin in the absence of fungi and was incubated and recovered under the same conditions.

Residual technical soda lignin PB1000 was recovered after fungal growth by the centrifugation of the culture medium on day 14. The insoluble fraction was analyzed by HPSEC and quantitative ${ }^{31} \mathrm{P}$ NMR (Ascend $400 \mathrm{MHz}$ Spectrometer, Bruker). The thioacidolysis monomers p-hydroxyphenyl $(\mathrm{H})$, guaiacyl $(\mathrm{G})$, and syringyl (S) were also analyzed as their trimethylsilyl derivatives by gas chromatography-mass spectrometry (GC-MS, Saturn 2100, Varian, Palo Alto, CA, USA) as previously described [46]. The GC-MS apparatus was equipped with a poly (dimethylsiloxane) capillary column $(30 \mathrm{~m} \times 0.25 \mathrm{~mm}$; SPB-1, Supelco, Bellefonte, PA, USA) operating in the temperature program $\left(40\right.$ to $180{ }^{\circ} \mathrm{C}$ at $30{ }^{\circ} \mathrm{C} / \mathrm{min}$, then 180 to $260{ }^{\circ} \mathrm{C}$ at $\left.2{ }^{\circ} \mathrm{C} / \mathrm{min}\right)$. The determination of the thioethylated $\mathrm{H}, \mathrm{G}$, and $\mathrm{S}$ monomers was performed from ion chromatograms reconstructed at $m / z 239,269$, and 299 , respectively, as compared to the internal standard (heneicosane) signal measured from the ion chromatogram reconstructed at $m / z(57+71+85)$.

The detailed description of the analysis methods and the parameters used have been previously described [42].

\subsection{Proteomic Analysis}

The proteomic analysis was performed as previously described [42] at PAPPSO platform facilities (http: / / pappso.inra.fr / , accessed 7 August 2021) for protein identification. LC-MS/MS analyses were performed using a NanoLC Ultra system (Eksigent, Dublin, CA, USA) connected to a Q-Exactive Plus mass spectrometer (Thermo Fisher Scientific) and an Ultimate 3000 RSLC system (Thermo Fisher Scientific, Waltham, MA, USA) coupled to an LTQ-orbitrap discovery mass spectrometer (Thermo Fisher Scientific) by nanoelectrospray ion source on both systems.

All MS/MS spectra were integrated against the JGI databases for T. reseei v2.0 ( https: / genome.jgi.doe.gov/Trire2/Trire2.home.html, accessed 7 August 2021) using the X!TandemPipeline (X!Tandem version 3.4.3), the open search engine developed by PAPPSO (http:/ / pappso.inra.fr/bioinfo/xtandempipeline/, accessed 7 August 2021). Data filtering was achieved according to a peptide $E$-value $<10^{-2}$, protein $E$-value $<10^{-3}$ and to a minimum of two identified peptides per protein. As some of the proteins were only detected by one of the used methods, identifications from both mass spectrometers were combined.

All amino acid sequences were obtained from JGI Mycocosm [47].

\subsection{Phylogenetic Study and Sequence Alignments}

The sequences selected to build this tree are public accessions from NCBI (https: / / www.ncbi.nlm.nih.gov / , accessed 7 August 2021) and JGI. (https: / / mycocosm.jgi.doe. gov/mycocosm/home, accessed 7 August 2021). These were cleaned of their peptide signal and WSC domain(s) (cell wall integrity and stress response components) when present. The multi-copy sequences from a single organism have been removed to avoid redundancy. Only one representative sequence was included. A multiple alignment was performed using MAFFT tool (version 7) following the accuracy-oriented method and the option maxiterate 1000 input [48]. The quality of the alignment was confirmed by the transitive consistency score [49]. TrimAl v1.2 was used to automatically remove spurious or misaligned sequences with the automated option [50]. The phylogenetic tree was produced from the NGphylogeny [51] and PhyML [52] (version 3.0) and formatted using iTOL [53]. Lignin copper oxidase ( $\operatorname{Tr} \mathrm{LOx}$ ) protein domains were predicted using NCBI Conserved Domain Search [54]. The molecular structure was modelled using Phyre2 [55] and the images were generated using Pymol Molecular Graphics System (Version 2.0, Schrödinger, LLC, New York, NY, USA). 


\subsection{Production of TrLOx in Pichia pastoris}

The sequence encoding TrLOx (GenBank accession number: MZ436831) was previously identified in the genome of $T$. reesei [56]. The native signal peptide sequence was removed (MKPSPVASLLSVSLLSLTSCHA), and the CDNA sequence was codon optimized for P. pastoris expression and synthesized (Genewiz, Leipzig, Germany). The synthetic gene was cloned in pPICZ alpha A (Invitrogen, Cergy-Pontoise, France) vector in the $\mathrm{XhoI} / \mathrm{XbaI}$ site in frame with both the $\alpha$-factor and the His6 tag at the $\mathrm{C}$ terminus of the recombinant protein. Escherichia coli strain DH5 $\alpha$ (Invitrogen) was used for vector storage and propagation.

pPICZ $\alpha$ A recombinant plasmids were linearized with PmeI and used to transform competent P. pastoris SuperMan 5 cells (BioGrammatics, Carlsbad, CA, USA) by electroporation. Zeocin-resistant $P$. pastoris transformants were then screened for protein production. Electrocompetent cells preparation, electroporation and screening were carried out as previously described [57] and proteins were analyzed by SDS-PAGE.

The best-producing transformant was grown in $2 \mathrm{~L}$ buffered complex glycerol (BMGY) medium (10 g/L glycerol, $10 \mathrm{~g} / \mathrm{L}$ yeast extract, $20 \mathrm{~g} / \mathrm{L}$ peptone, $3.4 \mathrm{~g} / \mathrm{L}$ yeast nitrogen base (YNB), $10 \mathrm{~g} / \mathrm{L}$ ammonium sulfate, $100 \mathrm{mM}$ phosphate buffer $\mathrm{pH} 6$ and $0.2 \mathrm{~g} / \mathrm{L}$ of biotin) at $30{ }^{\circ} \mathrm{C}$ and $200 \mathrm{rpm}$ to an optical density at $600 \mathrm{~nm}$ of 2-6. Cultures were then centrifuged at $6000 \mathrm{rpm}$ for $5 \mathrm{~min}$ and the pellet was dissolved in $100 \mathrm{~mL}$ buffered methanol-complex (BMMY) medium (10 g/L yeast extract, $20 \mathrm{~g} / \mathrm{L}$ peptone, $3.4 \mathrm{~g} / \mathrm{L} \mathrm{YNB}, 10 \mathrm{~g} / \mathrm{L}$ ammonium sulfate, $100 \mathrm{mM}$ phosphate buffer $\mathrm{pH} 6$ and $0.2 \mathrm{~g} / \mathrm{L}$ of biotin) supplemented with $1 \mathrm{~mL} / \mathrm{L}$ Pichia trace minerals 4 (PTM4) salt solution. Protein production was induced at $20{ }^{\circ} \mathrm{C}$ and $200 \mathrm{rpm}$ by adding $3 \%$ methanol $(v / v)$ daily for 3 days. The culture supernatant was collected by centrifugation ( $4000 \mathrm{rpm}$ for $10 \mathrm{~min}$ at $4{ }^{\circ} \mathrm{C}$ ).

The preparation of the used media is described in the manufacturer's manual (Invitrogen).

\subsection{Protein Purification}

The $\mathrm{pH}$ of the collected culture supernatant was adjusted to 7.8 with $\mathrm{NaOH}(1 \mathrm{M})$ and sterile filtered (pore size; 0.22 m; Express Plus; Merck Millipore, Guyancourt, France). Immobilized metal affinity chromatography (IMAC) using an Äkta purifier (GE Healthcare Life Sciences, Buc, France) was used for the purification of His-tagged TrLOx protein. The sample was loaded onto a $5 \mathrm{~mL}$ HisTrap HP column prepacked with Ni Sepharose and equilibrated with binding buffer ( $50 \mathrm{mM}$ Tris- $\mathrm{HCl}, \mathrm{pH} 7.8,150 \mathrm{mM} \mathrm{NaCl})$. The proteins were eluted with $30 \%$ elution buffer ( $50 \mathrm{mM}$ Tris- $\mathrm{HCl}, \mathrm{pH}$ 7.8, $150 \mathrm{mM} \mathrm{NaCl}, 500 \mathrm{mM}$ imidazole). Recovered recombinant proteins were concentrated using $10 \mathrm{kDa}$ vivaspin concentrator (Sartorius, Aubagne, France) then dialyzed against $50 \mathrm{mM}$ sodium phosphate, $\mathrm{pH} 7$.

\subsection{Protein Characterization}

The concentration of the purified proteins was determined spectrophotometrically at $280 \mathrm{~nm}\left(\varepsilon=193,513 \mathrm{M}^{-1} \cdot \mathrm{cm}^{-1}\right)$ using a NanoDrop 2000 spectrophotometer (Thermo Fisher Scientific). Purified proteins were loaded onto $12 \%$ SDS-polyacrylamide gel, which was then stained with Coomassie blue, and the molecular mass of the protein was estimated according to the standard markers PageRuler prestained protein ladder (10 to $180 \mathrm{kDa}$; Thermo Fisher Scientific).

\subsection{Enzyme Activity}

The activity of $\operatorname{Tr} \mathrm{LOx}$ was measured spectrophotometrically by detecting the $\mathrm{H}_{2} \mathrm{O}_{2}$ dependent oxidation of ABTS (Sigma-Aldrich) by horseradish peroxidase (HRP; SigmaAldrich) $[36,58,59]$. The reaction mixture contained $50 \mathrm{mM}$ sodium tartrate buffer, $\mathrm{pH} 6$, 7 units of type II HRP, $0.1 \mathrm{mM}$ ABTS, $173 \mathrm{nM}$ TrLOx enzyme and $5 \mathrm{mM}$ of substrate. The reaction was initiated by the addition of the substrate, and the activity was followed spectrophotometrically at $420 \mathrm{~nm}$ and $30{ }^{\circ} \mathrm{C}$ for $2 \mathrm{~min}$. TrLOx activity was tested on 70 dif- 
ferent substrates purchased from Sigma-Aldrich including aromatic compounds, phenolics, aldehydes, ketones, carboxylic acids, furans, saccharides, lactones and alcohols (Table 1).

Table 1. Substrate specificity of TrLOx.

\begin{tabular}{|c|c|c|}
\hline & Substrate & Activity (nkat/mg) \\
\hline Phenolic & $\begin{array}{c}\text { Syringyl alcohol } \\
\text { Caffeic acid methyl ester } \\
\text { p-coumaric acid methyl ester } \\
\text { Vanillin } \\
\text { Acetovanillone } \\
\text { Homovanillic acid } \\
\text { Sinapic acid } \\
\text { Isovanillin } \\
\text { 4-Ethylphenol } \\
\text { Vanillyl alcohol } \\
\text { p-coumaryl alcohol } \\
\text { 4-vinylguaiacol } \\
\text { p-hydroxybenzaldehyde } \\
\text { Syringol } \\
\text { Syringaldehyde } \\
\text { p-coumaric acid } \\
\text { Syringic acid } \\
\text { Sinapic acid methyl ester } \\
\text { Homovanillyl alcohol } \\
\text { Eugenol } \\
\text { Vanillyl acetone } \\
\text { Ferulic acid } \\
\text { Ferulic acid methyl ester } \\
\text { Coniferyl alcohol } \\
\text { Guaiacol } \\
\text { 4-ethylguaiacol } \\
\text { Vanillic acid } \\
\text { Caffeic acid } \\
\text { Chlorogenic acid } \\
\text { Phenol }\end{array}$ & $\begin{array}{l}0.44 \pm 0.01 \\
0.24 \pm 0.01 \\
0.18 \pm 0.01 \\
0.12 \pm 0.01 \\
0.10 \pm 0.02 \\
0.08 \pm 0.01 \\
0.05 \pm 0.001 \\
0.05 \pm 0.01 \\
0.04 \pm 0.01 \\
0.03 \pm 0.001 \\
0.02 \pm 0.01 \\
\text { nd } \\
\text { nd } \\
\text { nd } \\
\text { nd } \\
\text { nd } \\
\text { nd } \\
\text { nd } \\
\text { nd } \\
\text { nd } \\
\text { nd } \\
\text { nd } \\
\text { nd } \\
\text { nd } \\
\text { nd } \\
\text { nd } \\
\text { nd } \\
\text { nd } \\
\text { nd } \\
\text { nd }\end{array}$ \\
\hline Carbohydrate & $\begin{array}{c}\text { Xylose } \\
\text { Galactose } \\
\text { Glucose } \\
\text { Raffinose } \\
\text { Cellobiose } \\
\text { Fructose } \\
\text { Maltose } \\
\text { Maltotriose }\end{array}$ & $\begin{array}{c}1.73 \pm 1.31 \\
1.27 \pm 0.37 \\
0.64 \pm 0.01 \\
0.44 \pm 0.01 \\
\text { nd } \\
\text { nd } \\
\text { nd } \\
\text { nd }\end{array}$ \\
\hline Furan & $\begin{array}{c}\text { Furfuryl alcohol } \\
\text { 5-Hydroxymethylfurfural } \\
\text { 5-Hydroxymethyl-2-furancarboxylic acid } \\
\text { 5-formylfuran-2-carboxylic Acid } \\
\text { Furfural } \\
\text { Furan-2,5-dicarbaldehyde }\end{array}$ & $\begin{array}{l}12.13 \pm 0.29 \\
1.30 \pm 0.36 \\
0.43 \pm 0.02 \\
0.30 \pm 0.08 \\
\quad \text { nd } \\
\text { nd }\end{array}$ \\
\hline Alcohol & $\begin{array}{c}\text { Veratryl alcohol } \\
\text { 2-phenylethanol } \\
\text { 1-phenyl-3-propanol } \\
\text { Glycerol } \\
\text { Cinnamyl alcohol } \\
\text { 1-phenylethanol } \\
\text { Sorbitol } \\
\text { ( } \pm \text { )-2-octanol } \\
\text { Methanol } \\
\text { Diethanolamine } \\
\text { Triethanolamine }\end{array}$ & $\begin{array}{l}5.49 \pm 1.36 \\
4.43 \pm 0.22 \\
1.92 \pm 0.04 \\
1.91 \pm 0.09 \\
0.99 \pm 0.01 \\
0.81 \pm 0.06 \\
\text { nd } \\
\text { nd } \\
\text { nd } \\
\text { nd } \\
\text { nd }\end{array}$ \\
\hline
\end{tabular}


Table 1. Cont.

\begin{tabular}{ccc}
\hline & Substrate & Activity (nkat/mg) \\
\hline & Dihydroxyacetone & $268.86 \pm 5.71$ \\
& Methylglyoxal & $26.30 \pm 1.15$ \\
& Glyoxylic acid & $1.73 \pm 0.16$ \\
& Veratric acid & $0.93 \pm 0.02$ \\
Aldehyde, Ketone, & Formaldehyde & $0.76 \pm 0.11$ \\
Carboxylic acid & Glyceraldehyde & $0.64 \pm 0.02$ \\
& Glyoxal & $0.51 \pm 0.03$ \\
& Acetaldehyde & nd \\
& Veratraldehyde & nd \\
& Phenyl glyoxylic acid & nd \\
& Acetone & nd \\
\hline Quinone & Acetophenone & nd \\
\hline Aniline & Benzoquinone (quinone) & nd \\
\hline Lactone & Ortho-anisidine (aniline) & nd \\
\hline
\end{tabular}

nd: not detected.

The effect of the metal ions $\mathrm{Cu}^{2+}, \mathrm{Mg}^{2+}, \mathrm{Ni}^{2+}, \mathrm{Co}^{2+}, \mathrm{Mn}^{2+}, \mathrm{Fe}^{2+}$ and $\mathrm{Zn}^{2+}$ was determined by measuring enzyme activity after pre-incubating the enzyme with $1 \mathrm{mM}$ or $10 \mathrm{mM}$ of metal for $0.5 \mathrm{~h}, 4 \mathrm{~h}$ and $24 \mathrm{~h}$ at $25^{\circ} \mathrm{C}$ and $450 \mathrm{rpm}$ shaking. The effects of the chelating agent EDTA and the inhibitor sodium azide were determined in a similar way.

$\operatorname{Tr} \mathrm{LOx}$ stability in $\mathrm{H}_{2} \mathrm{O}_{2}$ was investigated by incubating the enzyme with different concentrations $(2,4,6,8$ and $10 \mathrm{mM})$ of $\mathrm{H}_{2} \mathrm{O}_{2}$ over different time periods $(2,4$ and $24 \mathrm{~h})$ at $4{ }^{\circ} \mathrm{C} . \mathrm{H}_{2} \mathrm{O}_{2}$ was removed before adding the enzyme to the reaction mixture by washing the samples with buffer in NanoSEP OMEGA membrane $10 \mathrm{kDa}$ centrifugal devices (PALL, Saint-Germain-en-Laye, France).

In both assays, the standard activity assay was followed with $10 \mathrm{mM}$ dihydroxyacetone as substrate. Enzyme activity is given as nanokatals per milligram of protein used in the reaction (nkat/mg), where 1 kat is the conversion rate of $1 \mathrm{~mol}$ of substrate per second. Relative activity was calculated as percentage of the activity in the absence of the tested compounds.

\subsection{Steady-State Kinetics}

The kinetic constants for $\mathrm{Tr} \mathrm{LO}$ were determined following the standard activity test and using dihydroxyacetone $(0.005-100 \mathrm{mM})$, methylglyoxal $(0.3-50 \mathrm{mM})$, galactose $(0.3-$ $1000 \mathrm{mM})$, glycerol (0.3-1000 mM), furfuryl alcohol (1-100 mM) and 2-phenylethanol (6-50 $\mathrm{mM})$ as substrates. The Michaelis-Menten plots were used to calculate the kinetic parameters using OriginPro, Version 2020b (OriginLab Corporation, Northampton, MA, USA).

The generated $\mathrm{H}_{2} \mathrm{O}_{2}$ during $\operatorname{Tr} \mathrm{LOx}$ activity on the selected substrates was also measured in a coupled reaction with HRP/Amplex Red (Thermo Fisher Scientific). The reaction was carried out as described previously with modifications [60]. A total volume of $100 \mu \mathrm{L}$ contained $100 \mathrm{mM}$ tartrate buffer $\mathrm{pH}$ 6, $50 \mu \mathrm{M}$ Amplex Red, 7.1 U/mL HRP, $173 \mathrm{nM}$ TrLOx and $1 \mathrm{mM}$ substrate. The fluorescence was followed at an excitation wavelength of $560 \mathrm{~nm}$ and an emission wavelength of $595 \mathrm{~nm}$ using a Tecan Infinite M200 plate reader (Tecan, Männedorf, Switzerland). The slope from the standard curve relating $\mathrm{H}_{2} \mathrm{O}_{2}$ concentration and fluorescence was used to calculate the amount of generated $\mathrm{H}_{2} \mathrm{O}_{2}$ over time (0-20 $\mu \mathrm{M}$ $\mathrm{H}_{2} \mathrm{O}_{2} ; 374.34$ counts/ $\left.\mu \mathrm{mol}\right)$.

\subsection{Temperature and $p H$ Effect}

The optimum temperature was determined against dihydroxyacetone from $20{ }^{\circ} \mathrm{C}$ to $80^{\circ} \mathrm{C}$, with $5^{\circ} \mathrm{C}$ increments. The $\mathrm{pH}$ optimum was measured in sodium tartrate and sodium phosphate buffers over a $\mathrm{pH}$ range of 2 to 6 and 6 to 8 , respectively, in $0.5 \mathrm{pH}$ unit increments. 
The thermal stability was determined by incubating the enzyme at 30, 40, 50, 60, and $70{ }^{\circ} \mathrm{C}$ for $0.5,1,2,4,6,8,24$ and $48 \mathrm{~h}$. The enzyme was cooled on ice for $5 \mathrm{~min}$ before measurement.

Similarly, the $\mathrm{pH}$ stability was analyzed by incubating the enzyme at $4{ }^{\circ} \mathrm{C}$ for $1,2,4,6$, 8,24 and $48 \mathrm{~h}$ in sodium tartrate and sodium phosphate buffers in a pH range of 2 to 6 and 6 to 8 , respectively, in $0.5 \mathrm{pH}$ unit increments.

The residual activities were calculated as percentage of the measured activity before incubation.

\subsection{Activity of TrLOx on Lignin Derivatives}

The activity of $\operatorname{Tr} \mathrm{LOx}$ on the lignin-derived molecules syringol and syringyl alcohol was investigated by LC-MS. The reaction mixtures containing $10 \mathrm{mM}$ of the substrate were incubated for $24 \mathrm{~h}$ at $30{ }^{\circ} \mathrm{C}$ and $850 \mathrm{rpm}$ shaking and filtered $(0.45 \mu \mathrm{m}, \mathrm{GHP}$ Acrodisc, Pall Gelman, Port Washington, NY, USA) before injection analysis on UltiMate 3000 LC system (Thermo Fisher Scientific) combined with an electrospray ionization mass spectrometer (ISQ-EM, Thermo Fisher Scientific). Analysis was performed using BEH C18 column (particle size $1.9 \mu \mathrm{m}$, length $150 \mathrm{~mm}$, Waters, Milford, MA, USA). The samples were loaded at $0.2 \mathrm{~mL} / \mathrm{min}$ and $30{ }^{\circ} \mathrm{C}$. Used solvents were $0.2 \%$ formic acid (solvent A) and $100 \%$ acetonitrile (solvent B). Separation was achieved by multi-step gradient from 5-80\% solvent B in 52 min. Negative and positive ion ESI-MS spectra $(10-2000 \mathrm{~m} / \mathrm{z})$ were acquired (vaporizer temperature $61^{\circ} \mathrm{C}$, ion transfer temperature $300^{\circ} \mathrm{C}$, sheath gas pressure $21.8 \mathrm{psig}$, Auxiliary gas pressure $2.4 \mathrm{psig}$, sweep gas pressure $0.5 \mathrm{psig}$ ). The peaks were assigned according to the mass of the deprotonated (negative mode) and protonated (positive mode) ions and fragmentation pattern, and to the theoretical masses expected after the injection of pure commercial compounds.

The activity of $\operatorname{TrLOx}$ on three lignin dimers was assessed by HPSEC. The reactions were carried out for $24 \mathrm{~h}$ at $30{ }^{\circ} \mathrm{C}$ with $850 \mathrm{rpm}$ shaking and 3 different lignin dimers were used as substrates: BMA32 (SS $\beta$ O4), AMA170 (SS syringaresinol) and AMA181 (GG $\beta 5$ ). The dimers were synthesized using previously described methods [61] for dimers BMA32, AMA170 and [62] for dimer AMA181). The description of the HPSEC and LC-MS analysis and the parameters used have been previously detailed [42].

\section{Results and Discussion}

\subsection{T. reesei Growth on Lignin}

The ability of T. reseei BRFM 1104 to grow on $10 \mathrm{~g} / \mathrm{L}$ soda lignin derived from wheat straw was investigated over a 14-day period. Fungal growth was observed on lignincontaining plates and the average radial expansion on this substrate was $0.62 \mathrm{~cm} /$ day (Figure S1A). Supplementing the plates with glucose increased the radial expansion rate to $0.89 \mathrm{~cm} /$ day and enhanced sporulation (Figure S1B). However, the typical green spores were also observed on lignin-alone-containing plates.

The growth in liquid cultures was measured by extracting and quantifying fungal genomic DNA. Although growth was greater in maltose-supplied medium, T. reesei was still able to grow on lignin alone with maximum growth reached after day 3 and the total quantified fungal genomic DNA was found to decrease overtime in both conditions (Figure S1C). This can be explained by cell death and DNA denaturation in the minimal culture medium containing only lignin.

The growth and sporulation in the absence of carbon source other than lignin indicates that $T$. reesei can use this complex polyaromatic as a source of nutrients to complete its lifecycle. Extensive studies on lignin modification were carried out using basidiomycetes while ascomycetes have been described for their specificity towards plant polysaccharides. T. reesei for example, is widely used for the commercial production of hemicellulases and cellulases, however, very little is known about its potential role in lignin modification. A number of studies have reported the growth and activity of ascomycetes on lignin-rich wood substrates [27,63-66]. The fungus Phoma herbarum utilized natural LignoBoost kraft 
lignin, lignosulphonate, lignin extracted from spruce wood and synthetic lignin as a sole carbon source [67-69]. On the other hand, only two studies involved Trichoderma strains including T. viride, and eighteen Trichoderma strains isolated from lignocellulose composts. The growth of $T$. viride on basal mineral salt agar plates supplemented with $0.5 \%$ lignin have been qualitatively followed and the fungi showed mycelial growth as bluish-green patches under this condition; however, the source of the lignin substrate used was not specified [70]. The ligninolytic activity of Trichoderma strains isolated from lignocellulose composts have been evaluated by measuring the decolorization effect, the enzymatic activity and the concentration of released phenolic compounds during growth on dark post-industrial lignin (wastewater originating from the pulp and paper industry) [71]. The release of greater amounts of phenolics during growth on this substrate was associated with high superoxide dismutase-like and horseradish-like activities. To our knowledge, this study represents the first report confirming that $T$. reesei can grow and utilize a technical soda lignin.

\subsection{Characterization of Residual Lignin}

The analysis of released soluble lignin monomers and oligomers after 14 days growth of $T$. reesei revealed changes in the composition of this substrate, characterized by a significant decrease in soluble high molar mass compounds (elution time $<18 \mathrm{~min}$ ) (Figure 1A). LC-MS analysis confirmed that the small phenolic molecules, vanillin, $p$-coumaric acid and syringaldehyde almost completely disappeared in the fungal culture (Figure S2). This was paralleled by an increase in the lignin-derived monomers $p$-OH-benzaldehyde, syringic acid, and acetosyringone. The formation of acid compounds was probably due to the enzymatic oxidative conversion of phenolic lignin side chains. The presence of benzaldehyde, on the other hand, indicates that ligninolysis is happening through $\mathrm{C} \alpha-\mathrm{C} \beta$ cleavage reactions [72].

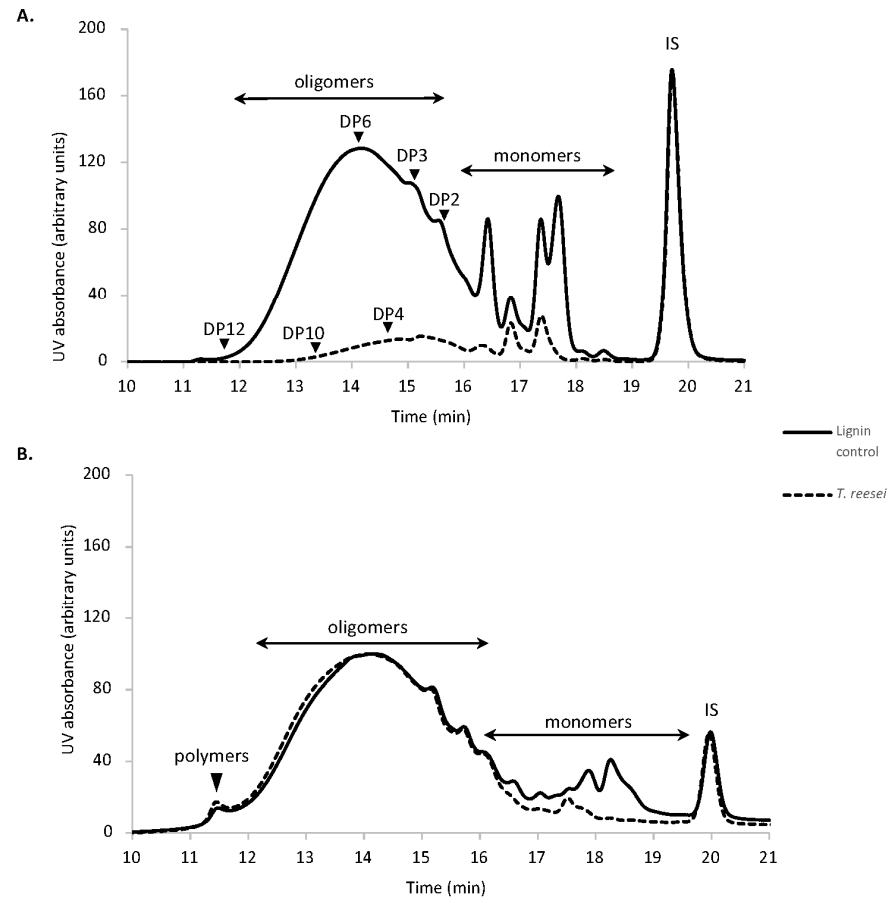

Figure 1. HPSEC analysis of residual lignin substrate. (A) water-soluble residual lignin fraction and (B) water insoluble residual lignin fraction. HPLC was performed on the ethyl acetate extracts of the culture supernatants and pellets recovered from soda lignin after 14-day incubation with $T$. reesei; chromatograms normalized on IS. Eluent tetrahydrofuran (THF), $1 \mathrm{~mL} / \mathrm{min}$; detection at $280 \mathrm{~nm}$; $100 \AA$ A PL-gel column (Polymer Laboratories, $5 \mu \mathrm{m}, 600 \mathrm{~mm} \times 7.5 \mathrm{~mm}$ ). The lignin control was dissolved in the culture media in the absence of fungi and incubated under the same conditions. DP: degree of polymerization, IS: internal standard is toluene. 
HPSEC analysis of the insoluble lignin fractions indicated the consumption of almost all the phenolic monomers (Figure 1B). Structural analysis of this fraction revealed a decrease of total free phenol content and a $67 \%$ decrease in the thioacidolysis yield, suggesting that $T$. reesei modified the structure of lignin by cleaving the $\beta$-O-4 linkages (Table S1). These structural features have also been observed during growth of Podospora anserina on lignin-rich wood substrates [26,27]. A shift in the first peak representing oligomers to a shorter retention was observed after fungal treatment and the polymers peak accumulated into the higher area, indicating that polymerization reactions are also taking place.

\subsection{Proteomic Analysis}

To link the observed structural changes to potential enzymatic activities, proteomic analysis of the secreted proteins during growth on lignin was performed. Previously, the production of ligninolytic enzymes by ascomycetes was mainly demonstrated by the discoloration of structurally similar dyes and measuring enzymatic activities (lignin peroxidase, manganese peroxidase and laccase) in the culture supernatants $[27,73,74]$. In this study, we report for the first time the enzymes produced by $T$. reesei during growth on technical lignin. In total, 245 proteins were identified in the secretome during growth on lignin alone (Table S2) and the highest number of proteins was detected on day 7 of growth (Figure 2). The induced CAZymes (95 proteins) belonged predominantly to the glycoside hydrolases $(\mathrm{GH})$ families, with $14 \mathrm{GHs}$ being detected exclusively in the absence of maltose. T. reesei also secreted two polysaccharide lyases and five carbohydrate esterases (CE), including CE1, CE5, CE9 and CE16.

A.

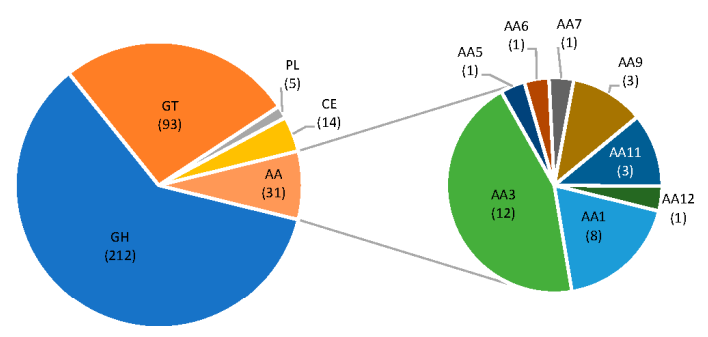

B.

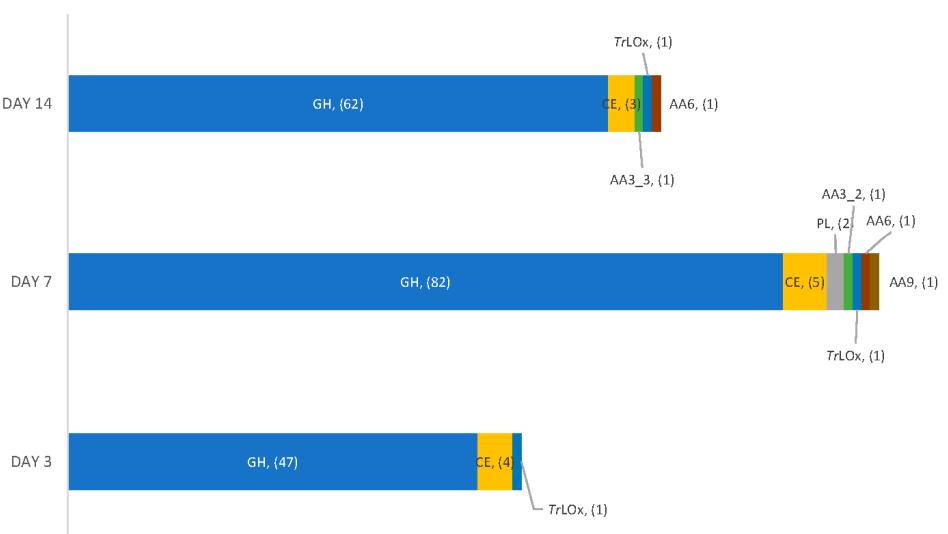

Figure 2. Distribution of CAZymes in genome and secretome of T. reesei. (A) genome and (B) secretome of T. reesei on lignin at days 3, 7 and 14 of growth. AA, auxiliary activity enzymes; GH, glycoside hydrolases; GT, glycosyl transferases; PL, polysaccharide lyases; CE, carbohydrate esterases; AA1, multicopper oxidases; AA2, class II lignin-modifying peroxidases; AA3, glucose-methanol-choline (GMC) oxidoreductases; AA3_2, aryl alcohol oxidase and glucose 1-oxidase; AA3_3, alcohol oxidase; AA5, copper radical oxidases; AA6, 1,4-benzoquinone reductase; AA7, glucooligosaccharide oxidases; AA9, AA11 and AA14 lytic polysaccharide monooxygenases; AA12, pyrroloquinoline quinone-dependent oxidoreductase; TrLOx, lignin copper oxidase. 
Out of the 31 predicted auxiliary activity CAZymes in the genome of T. reesei $[38,75,76]$, only 5 were detected in the secretome. Interestingly, all induced AA enzymes are hydrogen peroxide-producers. The role of these enzymes in lignin degradation was previously limited to the generation of hydrogen peroxide for the activity of peroxidases. However, the lack of lignin peroxidase- and manganese peroxidase-encoding genes in T. reesei and the detection of structural changes in lignin during growth suggest a direct role of enzymes of this type in lignin modification by this fungus. The accumulation of hydrogen peroxide leads to the generation of highly reactive hydroxyl free radicals which are able to depolymerize lignin and expose functional groups that can be in turn recognized and oxidized by these enzymes. However, $\mathrm{H}_{2} \mathrm{O}_{2}$ accumulation can also have a detrimental effect on fungal cells and enzymatic activity [77]. Interestingly, one peroxidase/catalase (JGI ID 70803) and one haem-peroxidase enzymes (JGI ID 73523) were detected in the secretome. The proteins have a signal peptide and were more abundant at day 7 of growth on lignin. The peroxidase/catalase protein identified in $T$. reesei secretome shared $58 \%$ sequence identity (Clustal Omega; Ref. [78]) with a previously described peroxidase/catalase from Podospora anserina (B2ASU5) which have been found to be required during growth and utilization of complex biomass like wood shavings and lignin [25]. This enzyme has also been found to play a major role in detoxifying $\mathrm{H}_{2} \mathrm{O}_{2}$ during vegetative growth. The secretion of these enzymes by $T$. reesei counterbalance the abundant presence of $\mathrm{H}_{2} \mathrm{O}_{2}$-producing AA enzymes and confers resistance to the oxidative damage during growth on lignin.

Secreted AAs included one putative aryl-alcohol oxidase (AAO)/glucose-1-oxidase (GO) (AA3_2) and one putative alcohol oxidase (AA3_3). These enzymes belong to the glucose-methanol-choline oxidase/dehydrogenase protein superfamily and are characterized by the presence of flavin adenine dinucleotide as a cofactor [79]. It has been shown that the enzymatic demethylation of lignin by fungi results in the accumulation of methanol which then induces the production of alcohol oxidases [80]. In addition, AAO is potentially implicated in lignin modification by acting on lignin-derived phenolic aromatic aldehydes and acids [81-83]. Enzyme belonging to the AA3 family were previously identified in the secretomes of several basidiomycetes $[84,85]$ and ascomycetes $[26,86]$ during growth on lignin-rich substrates.

Another detected AA enzyme during growth on lignin was 1,4-benzoquinone reductase (AA6). This enzyme catalyzes the reduction reactions of extracellular quinones producing hydroquinones that can in turn oxidize oxygen producing reactive oxygen species [87]. AA6 enzymes have been found to be induced by vanillin, vanillate, and quinones in the basidiomycete Phanerochaete chrysosporium [88] and are involved in the metabolism of low-molecular weight lignin fragments [89].

A lytic polysaccharide monooxygenase (LPMO, AA9) was also detected in the secretome at day 7 of growth. LPMO AA9s are known for their activity on cellulose microfibrils, and they have been identified in the secretomes of both ascomycetes and basidiomycetes during growth on lignocellulosic biomass [90]. Their role in lignin modification was very recently brought into light when the $\mathrm{H}_{2} \mathrm{O}_{2}$ generated by LPMO was favorably used for lignin oxidation by lignin-degrading peroxidases [91]. Interestingly, LPMO was exclusively detected in the condition containing technical lignin alone. The same finding was previously reported with Pycnoporus sanguineus and Leiotrametes menziesii [42], suggesting a role of these enzymes not only in cellulose deconstruction, but also directly in lignin modification. Alternatively, it could be that lignin-derived molecules are involved in the regulation of LPMO secretion on lignocellulosic biomass. It has also been shown that lignin polymer can act as the electron donor of LPMOs during cellulose oxidation significantly improving the enzymatic hydrolysis of cellulose [92].

During growth on lignin, T. reesei also secreted CRO (AA5). The fungus possesses only one gene encoding for an AA5 protein, and the enzyme was detected as early as day 3 of growth and remained detectable until day 14. The detection of this enzyme in the secretomes of T. reesei QM6a and three of its mutants have been previously reported during growth on cellulose fibrous as a major carbon source [93]. AA5 enzymes share similar 
tertiary structure but have very different catalytic properties and low overall sequence similarity $[36,39,58]$. They include AA5_1 (GLOX and other CRO), and AA5_2 enzymes (GalOx, raffinose oxidase and alcohol oxidases) and act on a broad range of substrates including alcohol- and aldehyde-containing molecules. Interestingly a large group of CRO fall within the group of "other copper radical oxidases" annotated as CRO1 to CRO6 and which functions are still unknown $[35,94]$. The secretion of these enzymes was previously reported in P. chrysosporium during growth on lignin and thin wood sections [94-96] and in Pycnoporus sanguineus and L. menziesii during growth on the same technical lignin used in the current study [42]. Previously reported CRO enzymes induced on lignin belonged to CRO1 (P. chrysosporium, Pycnoporus sanguineus, L. meziesii and Polyporus brumalis) CRO2 (Pycnoporus sanguineus, L. meziesii and Polyporus brumalis), CRO4 (P. chrysosporium) and CRO5 (Pycnoporus sanguineus, L. meziesii and Polyporus brumalis) groups [42,96]. However, the catalytic properties and the role of these enzymes in lignin modification have never been investigated.

\subsection{Phylogenetic Analysis}

As the detected AA5 was the first reported from ascomycete to be induced on technical lignin, the enzyme was targeted for heterologous production and in vitro characterization in the aim of elucidating its role in lignin modification. The enzyme is referred to as lignin oxidase (TrLOx). The phylogenetic tree grouping characterized and uncharacterized AA5_1 and AA5_2 enzymes from Basidiomycetes and Ascomycetes showed a clear distinction between the two subfamilies (Figure 3). The AA5_1 subfamily further separates into two subgroups with the first one containing mainly AA5_1 from Ascomycetes including TrLOx and the second AA5_1 from Basidiomycetes with few exceptions. TrLOx clusters with its homolog from $T$. virens which has been recently described for its role in normal hyphal growth and morphology [97]. However, the substrate profile of GLX1 from T. virens has not been investigated. In addition, none of the previously produced and characterized AA5 enzymes fell in the same subgroup containing $\operatorname{Tr} L \mathrm{Ox}$, suggesting possible divergent properties of this enzyme.

To identify variations in the amino acids previously described to be involved in catalysis such as copper coordination, and substrate recognition, TrLOx protein sequence was aligned with functionally characterized AA5_1 and AA5_2 enzymes (Figure S3). The alignments showed conserved copper coordinating residues (Cys252, Tyr311, Tyr533, His534 and His618). TrLOx shared higher similarity with characterized GLOX for residues known to be involved in catalysis and substrate recognition of D-galactose in AA5_2 enzymes [40].

TrLOx encoding sequence contained five WSC domains at the N-terminal end (Figure S4A). The function of this domain remains poorly studied. A recent study has shown no contribution of WSC domain to the catalytic activity of an alcohol oxidase from Pyricularia oryzae [98]. Instead, the authors have demonstrated a role of this domain in binding the enzyme to plant and/or fungal cell wall via xylans and fungal chitin/ $\beta-1,3-$ glucan. Furthermore, Crutcher et al. (2019) have shown that GLX1 from T. virens binds to chitin but not cellulose, lignin or peptidoglycan. Previously, a role in fungal responses to cell wall disruption, oxidation, high osmolarity, and metals stress have also been presented [99]. GLX1-silenced T. virens mutants have shown reduced sporulation, hydrophobicity and a loss of growth directionality in the hyphal tips due to the reduced production of $\mathrm{H}_{2} \mathrm{O}_{2}$ [97]. Taking these results into consideration, it is possible that the role of the WSC domain in $\operatorname{TrLOx}$ is to resist to the stress induced by the presence of technical lignin in the culture.

The predicted molecular structure of TrLOx generated with copper oxidase from Colletotrichum graminicola (PDB 6RYX) as template shows the conserved residues coordinating the catalytic copper ion H960, H1044, Y959, and Y737 that forms the characteristic thioether linkage to C678 (Figure S4C) [39,100,101]. 


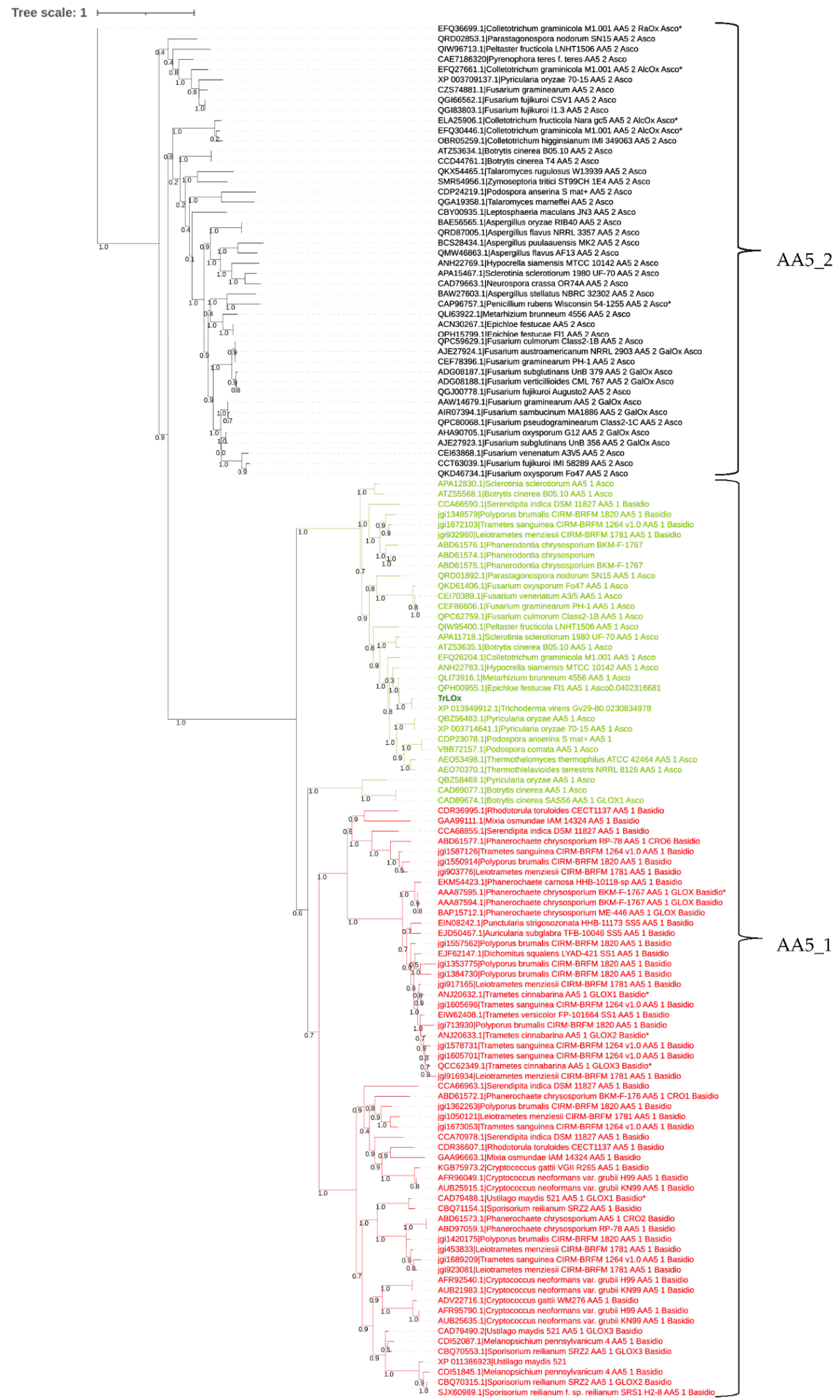

Figure 3. Phylogenetic tree of AA5 proteins. GenBank and JGI identifiers are given for all sequences. Subfamilies AA5_1 (green: from ascomycetes; red: from basidiomycetes) and AA5_2 (black) are indicated. Functionally characterized enzymes are indicated with a star $\left.{ }^{*}\right)$. Multiple sequence alignment was performed using MAFFT tool and the tree was constructed using NGphylogeny and PhyML. The branches represent evolutionary changes measured in unit of genetic divergence. The bar at the top provides the scale of the branch length. 


\subsection{Production of Active TrLOx}

The best-producing P. pastoris transformants were selected and used for the large-scale production of $\operatorname{Tr} \mathrm{LOx}$. IMAC purification yielded $32.5 \mathrm{mg} / \mathrm{L}$ of the recombinant protein. On SDS-PAGE, $\operatorname{Tr} \mathrm{LOx}$ showed a homogeneous single band at $\approx 150 \mathrm{kDa}, 34.2 \mathrm{kDa}$ larger than the theoretical molecular weight of the protein, suggesting the presence of glycosylation (Figure S4D). This was further supported by the prediction of $8 \mathrm{~N}$-glycosylation and 34 O-glycosylation sites using NetNGlyc 1.0 and NetOGlyc 4.0, respectively [102,103].

Enzymatic activity was assayed by following $\mathrm{H}_{2} \mathrm{O}_{2}$ production in a coupled reaction with HRP and ABTS. This method was previously used to measure the activity of glyoxal oxidases and galactose oxidases [36,58,59]. The specificity of $\operatorname{Tr} \mathrm{LOx}$ towards seventy different substrates was tested and the enzyme showed a broad range of activity (Table 1).

The highest activity was detected on dihydroxyacetone and the screening revealed a weak activity towards glyoxylic acid, the best previously reported substrate for GLOX from Pycnoporus cinnabarinus [36]. On the other hand, the activity on methylglyoxal, the best substrate for GLOX from Phanerochaete chrysosporium, was higher [58]. High activity on benzyl alcohols which are common structures in lignin was also observed. Furfuryl alcohol and veratryl alcohol were for example very competent substrates. Unlike other characterized GLOX enzymes, TrLOx showed weak activity on carbohydrates. These substrates are readily oxidized by the related enzyme, GalOx [104]. However, TrLOx was different from AA5_2 enzymes by showing higher activity on monosaccharides, notably xylose and no detectable activity on polysaccharides $[40,105]$. In addition, AA5_2 have very weak activity towards aliphatic, aromatic, phenolic and heterocyclic compounds compared to $\operatorname{Tr} \mathrm{LOx}$ [106]. Interestingly vanillin, which was found to decrease in the cultures of T. reesei on technical lignin was also oxidized by this enzyme.

The higher activity observed with dihydroxyacetone and methylglyoxal suggests that, in contrast to GLOX, the enzyme favors hydroxyl compounds and recognizes to a lesser extent aldehydes. In addition, polyols were very poor substrates which was reflected by the drastic difference in the detected activities on glycerol compared to dihydroxyacetone. Previously, dihydroxyacetone was found to be more efficiently oxidized by AA5_2 enzymes compared to the standard substrate galactose $[107,108]$. The substrate has been found to replace the water molecule at the equatorial site of the copper center [109]. Dihydroxyacetone can be hydrated generating gem-diol which have been found to be favored substrates for AA5_2 enzyme [110].

The preferential oxidation of alcohol to their corresponding aldehydes was further confirmed by product analysis of the oxidations of 5-hydroxymethyl furfural (HMF) derivatives (Figure S5). HMF is particularly important as by-product from biorefineries that can be transformed into high-value building blocks for green chemistry. The products of the oxidation of HMF and HMFCA by TrLOx were 2,5-furandicarboxaldehyde (DFF) and 5-formyl-2-furan carboxylic acid (FFCA), respectively, and no further conversion of DFF and FFCA was observed. TrLOx clearly favors the oxidation of the alcohol group of these substrates, further highlighting the difference with other AA5_1 enzymes such as GLOX [34]. Our results suggest that enzymes originating from the same subfamily AA5_1, namely TrLOx and GLOX, possess orthogonal activities and are potential candidates for one-pot conversion of HMF to furandicarboxylic acid (FDCA). The oxidation of the alcohol groups of HMF and HMFCA was previously reported for a newly characterized AA5_2 enzyme exhibiting aryl alcohol oxidase activity [101].

Kinetic analyses using preferred substrates revealed a classical Michaelian trend except for galactose and glycerol which appear as strictly linear plots (Figure S6). The highest catalytic efficiency was obtained on dihydroxyacetone $\left(K_{\mathrm{cat}} / K_{\mathrm{m}}=5.89 \mathrm{~s}^{-1} \mathrm{mM}^{-1}\right)$. However, $\operatorname{Tr} \mathrm{LOx}$ showed higher affinity to 2-phenylethanol $\left(K_{\mathrm{m}}=12.32 \mathrm{mM}\right)$, methylglyoxal $\left(K_{\mathrm{m}}=11.03 \mathrm{mM}\right)$ and furfuryl alcohol $\left(K_{\mathrm{m}}=6.72 \mathrm{mM}\right)$ compared to dihydroxyacetone $\left(K_{\mathrm{m}}=24.16 \mathrm{mM}\right)$ under the used conditions (Table 2). 
Table 2. Kinetic parameters of TrLOx with different substrates. Standard deviations are presented as plus-minus values.

\begin{tabular}{ccccc}
\hline Substrate & $\begin{array}{c}\boldsymbol{V}_{\mathbf{m a x}} \\
\text { (nkat/mg) }\end{array}$ & $\boldsymbol{K}_{\mathbf{m}}(\mathbf{m M})$ & $\boldsymbol{K}_{\text {cat }}\left(\mathbf{s}^{-\mathbf{1})}\right.$ & $\begin{array}{c}\boldsymbol{K}_{\text {cat }} / \boldsymbol{K}_{\mathbf{m}} \\
\left(\mathbf{s}^{-\mathbf{1}} \mathbf{~ m} \mathbf{M}^{-\mathbf{1}}\right)\end{array}$ \\
\hline Dihydroxyacetone & $2455.81 \pm 56.25$ & $24.16 \pm 1.44$ & 142.19 & 5.89 \\
Methylglyoxal & $46.84 \pm 6.39$ & $11.03 \pm 2.84$ & 1.08 & 0.10 \\
Furfuryl alcohol & $13.28 \pm 1.56$ & $6.72 \pm 1.91$ & 0.31 & 0.05 \\
2-Phenylethanol & $11.23 \pm 1.53$ & $12.32 \pm 5.18$ & 0.26 & 0.02 \\
\hline
\end{tabular}

$\mathrm{H}_{2} \mathrm{O}_{2}$ generation correlated with the measured activities on the selected substrates with the highest rate being detected in the reaction on dihydroxyacetone (Figure S7). The detected fluorescence peaked and then declined during the course of the reaction. This effect has been found to be triggered by different factors including the fluorescent product resorufin being itself a substrate for HRP, substrate inhibition and inactivation of HRP at high concentrations of hydrogen peroxide leading to a bell-shaped titration curve with hydrogen peroxide concentration range of 0.01 to $600 \mu \mathrm{M}$ [111] as observed in this study, notably with dihydroxyacetone.

\subsection{Biochemical Properties}

The effect of different metal ions, metal chelator and sodium azide on the stability and activity of $\operatorname{Tr} \mathrm{LOx}$ was investigated after treating the enzyme with $10 \mathrm{mM}$ of each molecule for 4 and $24 \mathrm{~h}$ (Figure $4 \mathrm{~A}$ ). Treatment with $10 \mathrm{mM} \mathrm{Cu}^{2+}$ for $4 \mathrm{~h}$ resulted in 4.5 times increase in enzymatic activity. Previously, adding copper sulfate to shake flask cultivations was found to double GalOx activity in the cultivation medium [112]. However, unlike $\operatorname{Tr} \mathrm{LOx}$, copper treatment of purified AA5_2 enzymes did not increase their specific activity $[105,112]$. Recombinant AA5 enzymes have been found to contain a mixture of fully coordinated proteins and apo-enzymes lacking copper [113]. The increase in activity for $\mathrm{Tr} \mathrm{LOx}$ suggests that the purified enzyme is not fully coordinated by $\mathrm{Cu}^{2+}$ ions from the culture media. No significant effect was observed with any of the other tested molecules after $4 \mathrm{~h}$ of incubation. The enzyme activity was reduced by $70 \%$ and $60 \%$ after $24 \mathrm{~h}$ of incubation with $\mathrm{Co}^{2+}$ and $\mathrm{Fe}^{2+}$, respectively. The loss in activity observed with the copper chelator EDTA (56\%) was comparable to previously published data obtained on a recombinant GalOx from Fusarium sambucinum [59]. However, unlike this enzyme which was completely inactive after incubation with sodium azide ( $5 \mathrm{mM} ; 5 \mathrm{~min}), \operatorname{Tr} \mathrm{LO}$ was significantly more stable retaining $60 \%$ of its activity after $24 \mathrm{~h}$ of incubation. Azide is thought to inhibit $\mathrm{GalOx}$ by replacing the water molecule in the catalytic center of the enzyme and blocking the substrate's binding site [114].

The stability of TrLOx over time in the presence of increasing concentrations of $\mathrm{H}_{2} \mathrm{O}_{2}$ was also investigated (Figure 4B). The enzyme was stable after incubation for two hours in up to $8 \mathrm{mM}$ of $\mathrm{H}_{2} \mathrm{O}_{2}$. A concentration-dependent decrease in residual activity was observed with increased incubation time and the enzyme was completely inactive after $24 \mathrm{~h}$ with $10 \mathrm{mM} \mathrm{H}_{2} \mathrm{O}_{2}$. The inhibition of the AA5_1 enzyme GLOX by exogenous $\mathrm{H}_{2} \mathrm{O}_{2}$ has been previously reported. $T r \mathrm{LOx}$ was significantly more stable than GLOX from P. chrysosporium ( $25 \%$ residual activity directly after adding $2.1 \mathrm{mM}$ exogenous $\mathrm{H}_{2} \mathrm{O}_{2}$ at $\mathrm{pH}$ ) and GLOX2 and GLOX3 from P. cinnabarinus (less than $10 \%$ residual activity after $24 \mathrm{~h}$ of incubation with $\left.8 \mathrm{mM} \mathrm{H}_{2} \mathrm{O}_{2}\right)[34,41]$. 


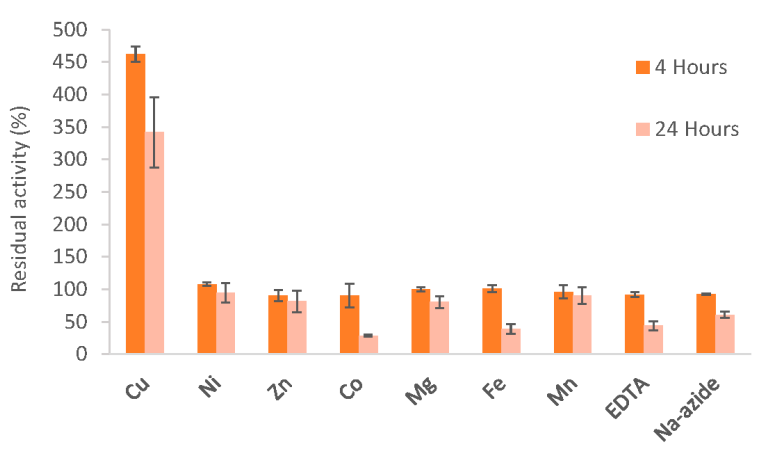

(A)

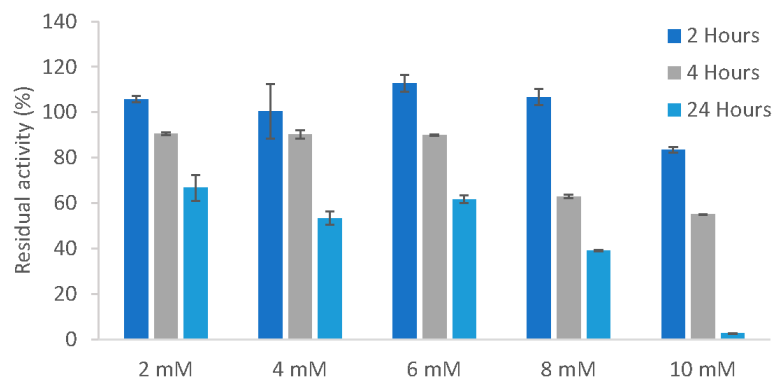

(B)

Figure 4. Enzyme stability in the presence of metals, inhibitors and $\mathrm{H}_{2} \mathrm{O}_{2}$. (A) Effect of $10 \mathrm{mM}$ of $\mathrm{Cu}, \mathrm{Ni}, \mathrm{Zn}, \mathrm{Co}, \mathrm{Mg}$, Fe, $\mathrm{Mn}$, EDTA and sodium azide on the enzymatic activity of TrLOx after incubation for 4 (dark orange) and $24 \mathrm{~h}$ (light orange); (B) Enzyme stability in the presence of increasing concentrations of hydrogen peroxide over an incubation period of 2,4 and $24 \mathrm{~h}$. Activities were calculated as a relative percentage of the activity in the absence of any molecule and reported as mean. Standard deviations are presented by error bars.

Dihydroxyacetone was used to determine the optimum $\mathrm{pH}$ and temperature for the activity of $\operatorname{Tr} \mathrm{LOx}$. The highest activity was detected at $\mathrm{pH} 6.5$ (Figure $5 \mathrm{~A}$ ) and $45^{\circ} \mathrm{C}$ (Figure 5B).

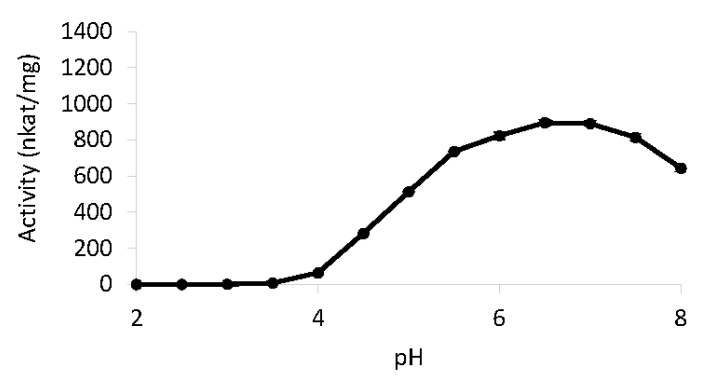

(A)

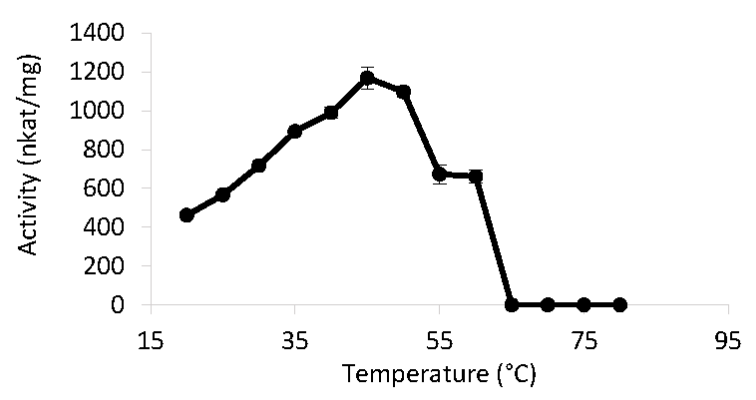

(B)

Figure 5. Optimum $\mathrm{pH}$ and temperature for the activity of TrLOx. (A) Activity in Sodium tartrate (pH 2-6) and sodium phosphate ( $\mathrm{pH}$ 6-8) buffers; (B) Measured enzymatic activity at different temperatures. Standard deviations are presented by error bars.

Tr $\mathrm{LOx}$ was very sensitive to acidic $\mathrm{pH}$, the enzyme showed high stability in a $\mathrm{pH}$ range of 4-8 (Figure 6A). TrLOx retained $34 \%$ of its activity after incubation at $40{ }^{\circ} \mathrm{C}$ for $8 \mathrm{~h}$ and was stable at $30^{\circ} \mathrm{C}$ (Figure 6B). No activity was detected when the enzyme was exposed to temperatures above $60^{\circ} \mathrm{C}$. The conditions under which TrLOx showed highest activity were comparable to previously characterized P. cinnabarinus GLOX enzymes ( $\mathrm{pH} 6$ and $50^{\circ} \mathrm{C}$ ) [36]. In addition, $\operatorname{Tr} \mathrm{LOx}$ was more stable at $30^{\circ} \mathrm{C}$ and less stable at temperatures exceeding $50^{\circ} \mathrm{C}$ compared to P. cinnabarinus GLOX. Similarly, P. chrysosporium GLOX has shown highest activity at $\mathrm{pH} 6$ and a sharp decrease in activity at $\mathrm{pH}$ below 5.5 [115]. However, P. chrysosporium GLOX has completely lost activity at $\mathrm{pH} 7.5$ and was not active in phosphate buffer. In comparison, AA5_2 enzymes have shown higher activity at $\mathrm{pH} 7-8$ and the activity was halved at pH $6[40,101,105]$. Similarly to TrLOx, characterized AA5_2 enzymes have also shown reduced thermal stability. 


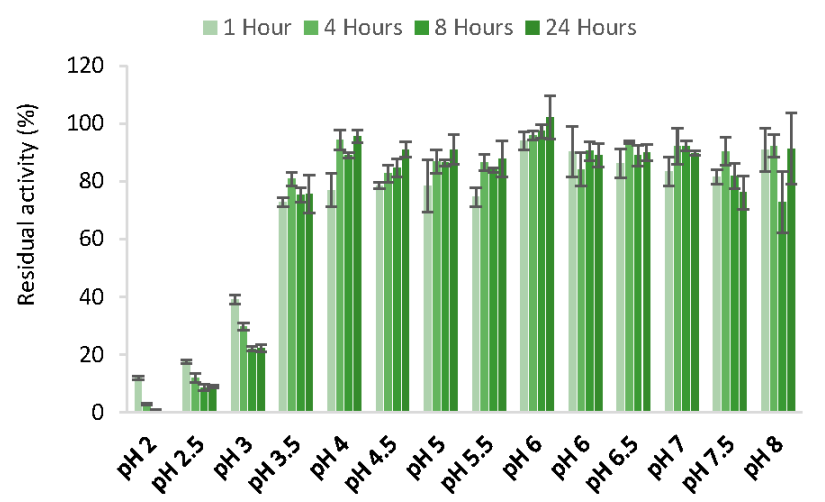

(A)

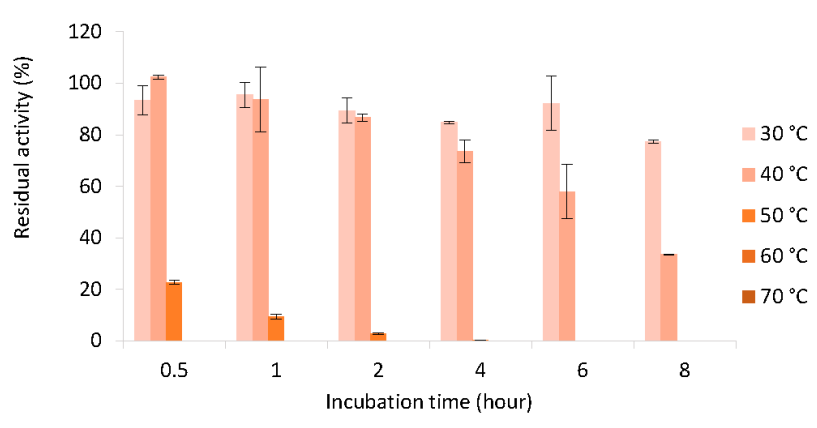

(B)

Figure 6. Enzyme stability under different $\mathrm{pH}$ and temperatures. (A) Stability after incubation for different time periods at $\mathrm{pH} 2-8$; (B) Stability after incubation for different time periods at $30-70{ }^{\circ} \mathrm{C}$. Measured enzymatic activity at different temperatures. Activities were calculated as a relative percentage of the activity before incubation. Mean values are reported, and standard deviations are presented by error bars.

\subsection{Does TrLOx Modify Lignin?}

Previous studies have presumed a role of CROs in lignin modification either directly or through the generation of hydrogen peroxide. Crutcher et al. (2019) have recently ruled out this hypothesis by showing that GLX1 from T. virens was not implicated in the breakdown of lignin as the enzyme was unable to bind lignin. However, the direct activity of CROs on this substrate and its derivatives and the resulting structural modifications have never been explored.

In this paper, the activity of TrLOx was investigated for the first time on syringol, syringaldehyde, and three lignin dimers: BMA32 (SS $\beta O 4)$, AMA170 (SS syringaresinol) and AMA181 (GG $\beta 5$ ). The tested dimers represent the major structural units in the polymer. TrLOx activity was followed by LC-MS and HPSEC. The HPSEC analysis showed that TrLOx had no activity on AMA170 (SS $\beta \beta$ ), whereas it had an activity on AMA181 (GG $\beta 5$ ) and BMA32 (SS $\beta \mathrm{O} 4$ ) (Figure 7), showing oligomers with polymerization degree (PD) up to 10. The LC-MS analysis confirmed that the observed reactions are oligomerization and oxidation of functional groups (alcohols into aldehydes). Concerning BMA32, though the main products formed are dimers and trimers of the initial substrate (PD 4 and 6), the detection of some oligomers by LC-MS with higher degree of polymerization (observed with the SS $\beta \mathrm{O} 4$ substrate) suggest that some bonds' cleavage might occur during the treatment or that the monomers present as traces in the initial material are involved in the oligomerization. It seems that the reactivity of the systems depends on the dimer type, which indicates enzymes specificities towards the functional groups present in these molecules. The activity of TrLOx was also compared to GLOX2 from Pycnoporus cinnabarinus for which no activity was noticed towards the three dimers compared to TrLOx.

In nature, plants incorporate numerous lignin monomers to form lignin by oxidation and coupling of monolignol radicals with the radicals on the phenolic ends of the lignin polymer. This reaction is initiated by the action of plant oxidative enzymes such as $\mathrm{O}_{2}$-dependent laccases and $\mathrm{H}_{2} \mathrm{O}_{2}$-dependent peroxidases and it serves not only for the production of lignin polymers but also to link this structure to the polysaccharides in the cell wall. Lignin polymerization was also previously reported in fungal cultures on lignin [73] and it was associated with the oxidation of lignin phenoxy radicals by secreted fungal laccases in the cultures [74]. The observed oxidation of the phenolic moieties of syringol to form syringol dimers shows that TrLOx polymerizes lignin following the same mechanism (Figure S8A). The enzyme seems to favor the oxidation of the hydroxy moiety of the hydroxymethyl group in syringyl alcohol (Figure S8B). In the case of lignin dimers, it is difficult to determine the exact coupling sites. However, the absence of activity on 
AMA170 suggest that the coupling most likely occurs between the oxidized alcohol groups at the hydroxypropenyl side chain and at the $\mathrm{C} 4$ position of the syringyl and guaiacyl units of BMA32 and AMA181, respectively (Figure 7). The oxidized new radical will then react either with new dimers or oligomers formed in the reaction resulting in oligomers with PD up to 10. This is further supported by the measured activity on cinnamyl alcohol and vanillin (Table 1). Regarding in-vivo conditions, polymerization is thought to be prevented by the presence of cooperative enzymes acting as quenchers to radical species. Several flavin adenine dinucleotide (FAD)-containing enzymes have been described to reduce phenoxy radicals and prevent lignin re-polymerization, including glucose oxidase [116], veratryl alcohol oxidase [117], cellobiose dehydrogenase [118], and pyranose-2-oxidase [119]. The latter not only prevented repolymerization, but also showed depolymerizing activity on lignosulfonate. This suggests that polymerizing enzymes such as laccase and TrLOx might act by activating lignin hydroxyl radicals for degradation by other secreted enzymes. Interestingly, one aryl-alcohol oxidase (AAO)/glucose-1-oxidase (GO) and one alcohol oxidase (AA3_3) were co-secreted with TrLOx in the cultures of T. reesei on technical soda lignin, further supporting this hypothesis. In addition, T. reesei secreted a 1,4-benzoquinone reductase which might be involved in the reduction of reactive phenoxy radicals and/or quinones formed during lignin breakdown converting them into more stable molecules. The effect of combined AA6 and lignin peroxidase on the depolymerization of technical lignins was very recently investigated and the study revealed that AA6 can to some extent limit the lignin re-polymerization by lignin peroxidase [120]. Further studies investigating the synergistic activity of TrLOx and the above-mentioned enzymes on lignin molecules are required to elucidate the mechanism behind lignin modification.
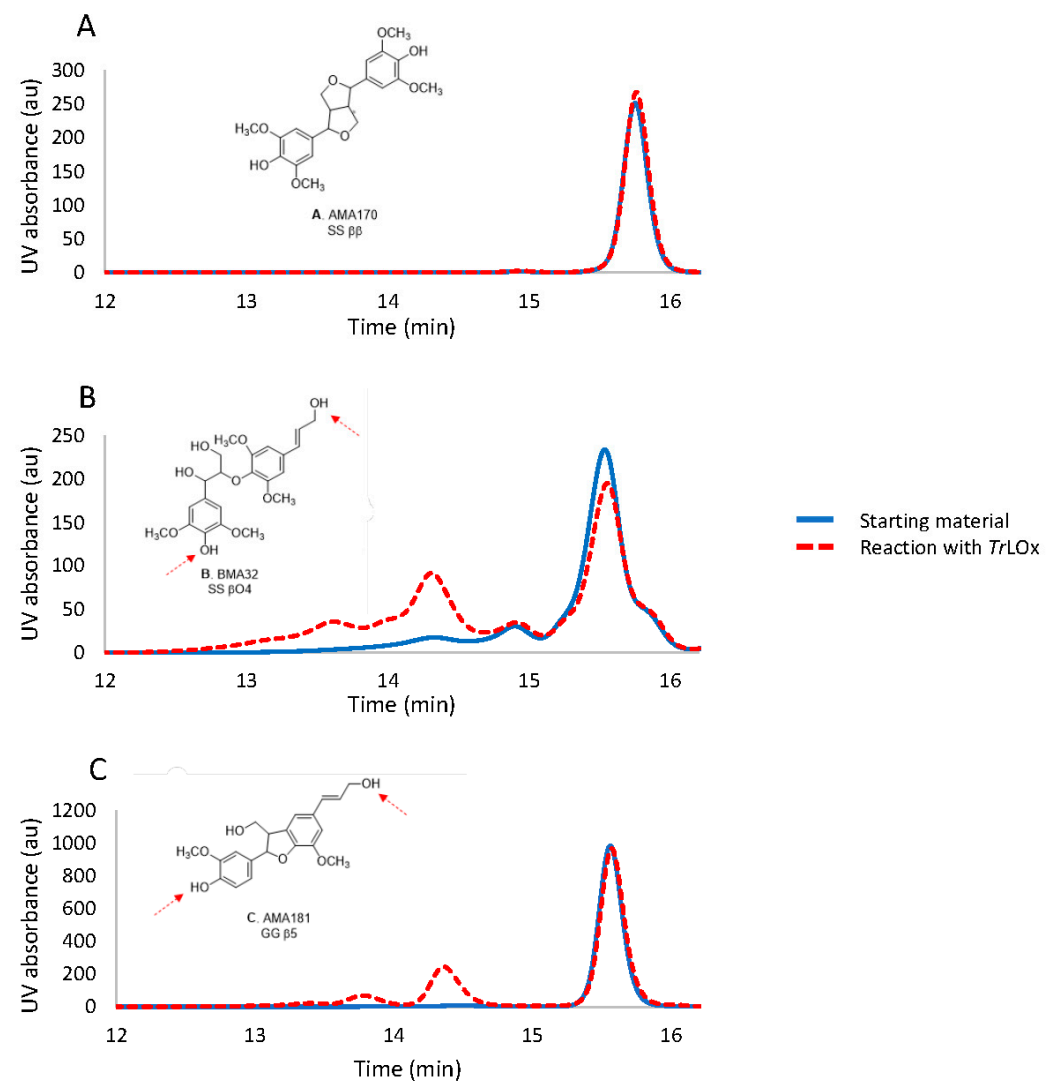

Figure 7. HPSEC-PDA (size-exclusion chromatography coupled to a photodiode array detector, absorbance $280 \mathrm{~nm}$ ) profiles of the starting dimer and their reactions with TrLOx, reaction with (A) AMA170, (B) BMA32 (C) AMA181; starting material (blue); reaction with TrLOx (red). The red arrows indicate the potential coupling site by the action of $\operatorname{Tr} \mathrm{LOx}$. 
The results in this study also introduced for the first time the potential of $\operatorname{TrLOx}$ for the synthesis of new homomolecular or heteromolecular molecules. Current applications in the biopolymer field include dye synthesis [121], cotton fibers functionalization [122], and hydrogels production for drug delivery and water treatment [123]. Such biopolymers are perfect examples of sustainable biotechnological application.

Supplementary Materials: The following are available online at https://www.mdpi.com/article/10 .3390 /jof7080643/s1, Figure S1: T. reesei growth on technical soda lignin, Figure S2: LC-MS analysis on water-soluble lignin fraction, Figure S3: Sequence alignment of 11 functionally characterized AA5 enzymes with TrLOx, Figure S4: Structural characteristics of TrLOx, Figure S5: HPLC analysis of TrLOx reactions on HMF and HMFCA, Figure S6: Michaelis-Menten plots for the activity of TrLOx on the different tested substrates, Figure S7: $\mathrm{H} 2 \mathrm{O} 2$ production overtime in the reaction of TrLOx on different substrates, Figure S8: LC-MS chromatograms of the reaction of TrLOx on Syringol and Syringyl alcohol. Table S1: Total phenolic and thioacidolysis yields of water-insoluble residual lignin after exposure to T. reesei, Table S2: Identified CAZymes in the secretomes during growth of T. reesei on technical lignin.

Author Contributions: M.D., A.B., M.H., C.B.F., S.B., E.R., D.N., B.C. and S.R. designed the experiments. M.D. performed the fungal cultures and growth quantification. M.D., A.B. and M.H. performed the heterologous production and M.D. performed the enzyme characterization. L.O.C. performed the proteomic analysis. E.D. provided the genomic data and created the phylogenetic tree. B.C. performed the chemical characterization of lignin and the HPSEC and LC-MS analysis on lignin dimer. D.N. performed the LC-MS analysis on synringol and synringic acid. M.D., C.B.F., S.B., L.O.C., B.C., D.N. and S.R. analyzed and interpreted the data and results. M.D. was the major contributor in writing the manuscript. C.B.F., S.B., B.C., L.O.C., E.B., S.G. and E.R. provided critical feedback and helped in writing the manuscript. All authors have read and agreed to the published version of the manuscript.

Funding: This study is part of the Zelcor project that has received funding from the Bio Based Industry Joint Undertaking under the European Union's Horizon 2020 research and innovation program under grant agreement No 720303. The IJPB benefits from the support of the LabEx Saclay Plant Sciences-SPS (ANR-10-LABX-552 0040-SPS).

Institutional Review Board Statement: Not applicable.

Informed Consent Statement: Not applicable.

Data Availability Statement: The data presented in this study are available on request from the corresponding author. The data are not publicly available due to confidentiality.

Conflicts of Interest: The authors declare no conflict of interest.

\section{References}

1. Pollegioni, L.; Tonin, F.; Rosini, E. Lignin-degrading enzymes. FEBS J. 2015, 282, 1190-1213. [CrossRef]

2. Berrin, J.-G.; Navarro, D.; Couturier, M.; Olivé, C.; Grisel, S.; Haon, M.; Taussac, S.; Lechat, C.; Courtecuisse, R.; Favel, A.; et al. Exploring the Natural Fungal Biodiversity of Tropical and Temperate Forests toward Improvement of Biomass Conversion. Appl. Environ. Microbiol. 2012, 78, 6483. [CrossRef] [PubMed]

3. Wan, C.; Li, Y. Fungal pretreatment of lignocellulosic biomass. Biotechnol. Adv. 2012, 30, 1447-1457. [CrossRef] [PubMed]

4. Salvachúa, D.; Prieto, A.; Vaquero, M.E.; Martínez, Á.T.; Martínez, M.J. Sugar recoveries from wheat straw following treatments with the fungus Irpex lacteus. Bioresour. Technol. 2013, 131, 218-225. [CrossRef]

5. Tuyen, V.D.; Cone, J.W.; Baars, J.J.P.; Sonnenberg, A.S.M.; Hendriks, W.H. Fungal strain and incubation period affect chemical composition and nutrient availability of wheat straw for rumen fermentation. Bioresour. Technol. 2012, 111, 336-342. [CrossRef]

6. Tuck, C.O.; Pérez, E.; Horváth, I.T.; Sheldon, R.A.; Poliakoff, M. Valorization of Biomass: Deriving More Value from Waste. Science 2012, 337, 695. [CrossRef] [PubMed]

7. de Vries, R.P.; Mäkelä, M.R. Genomic and Postgenomic Diversity of Fungal Plant Biomass Degradation Approaches. Trends Microbiol. 2020, 28, 487-499. [CrossRef]

8. Hage, H.; Miyauchi, S.; Virágh, M.; Drula, E.; Min, B.; Chaduli, D.; Navarro, D.; Favel, A.; Norest, M.; Lesage-Meessen, L.; et al. Gene family expansions and transcriptome signatures uncover fungal adaptations to wood decay. Environ. Microbiol. 2021. early view. [CrossRef]

9. Hage, H.; Rosso, M.-N. Evolution of Fungal Carbohydrate-Active Enzyme Portfolios and Adaptation to Plant Cell-Wall Polymers. J. Fungi 2021, 7, 185. [CrossRef] 
10. Zhou, S.; Raouche, S.; Grisel, S.; Sigoillot, J.; Herpoël-Gimbert, I. Efficient biomass pretreatment using the White-rot Fungus Polyporus Brumalis. Fungal Genom. Biol. 2017, 7, 1-6.

11. Jurak, E.; Suzuki, H.; van Erven, G.; Gandier, J.A.; Wong, P.; Chan, K.; Ho, C.Y.; Gong, Y.; Tillier, E.; Rosso, M.N.; et al. Dynamics of the Phanerochaete carnosa transcriptome during growth on aspen and spruce. BMC Genom. 2018, 19, 815. [CrossRef]

12. Daly, P.; López, S.C.; Peng, M.; Lancefield, C.S.; Purvine, S.O.; Kim, Y.M.; Zink, E.M.; Dohnalkova, A.; Singan, V.R.; Lipzen, A.; et al. Dichomitus squalens partially tailors its molecular responses to the composition of solid wood. Environ. Microbiol. 2018, 20, 4141-4156. [CrossRef] [PubMed]

13. Arntzen, M.Ø.; Bengtsson, O.; Várnai, A.; Delogu, F.; Mathiesen, G.; Eijsink, V.G.H. Quantitative comparison of the biomassdegrading enzyme repertoires of five filamentous fungi. Sci. Rep. 2020, 10, 20267. [CrossRef] [PubMed]

14. Miyauchi, S.; Hage, H.; Drula, E.; Lesage-Meessen, L.; Berrin, J.G.; Navarro, D.; Favel, A.; Chaduli, D.; Grisel, S.; Haon, M.; et al. Conserved white-rot enzymatic mechanism for wood decay in the Basidiomycota genus Pycnoporus. DNA Res. 2020, 27 , dsaa011. [CrossRef] [PubMed]

15. Lopes, A.M.; Ferreira Filho, E.X.; Moreira, L.R.S. An update on enzymatic cocktails for lignocellulose breakdown. J. Appl. Microbiol. 2018, 125, 632-645. [CrossRef]

16. Crawford, R.H.; Carpenter, S.E.; Harmon, M.E. Communities of Filamentous Fungi and Yeast in Decomposing Logs of Pseudotsuga Menziesii. Mycologia 1990, 82, 759-765. [CrossRef]

17. Fukasawa, Y.; Osono, T.; Takeda, H. Wood decomposing abilities of diverse lignicolous fungi on nondecayed and decayed beech wood. Mycologia 2011, 103, 474-482. [CrossRef]

18. Kirk, T.K.; Farrell, R.L. Enzymatic “combustion": The microbial degradation of lignin. Annu. Rev. Microbiol. 1987, 41, 465-505. [CrossRef]

19. Cragg, S.M.; Beckham, G.T.; Bruce, N.C.; Bugg, T.D.H.; Distel, D.L.; Dupree, P.; Etxabe, A.G.; Goodell, B.S.; Jellison, J.; McGeehan, J.E.; et al. Lignocellulose degradation mechanisms across the Tree of Life. Curr. Opin. Chem. Biol. 2015, 29, 108-119. [CrossRef] [PubMed]

20. Worrall, J.J.; Anagnost, S.E.; Zabel, R.A. Comparison of wood decay among diverse lignicolous fungi. Mycologia 1997, 89, 199-219. [CrossRef]

21. Nilsson, T.; Daniel, G. Chemistry and Microscopy of Wood Decay by Some Higher Ascomycetes. Holzforschung 1989, 43, 11-18. [CrossRef]

22. Shary, S.; Ralph, S.A.; Hammel, K.E. New insights into the ligninolytic capability of a wood decay ascomycete. Appl. Environ. Microbiol. 2007, 73, 6691-6694. [CrossRef] [PubMed]

23. Linley, E.; Denyer, S.P.; McDonnell, G.; Simons, C.; Maillard, J.Y. Use of hydrogen peroxide as a biocide: New consideration of its mechanisms of biocidal action. J. Antimicrob. Chemother. 2012, 67, 1589-1596. [CrossRef]

24. Xie, N.; Chapeland-Leclerc, F.; Silar, P.; Ruprich-Robert, G. Systematic gene deletions evidences that laccases are involved in several stages of wood degradation in the filamentous fungus Podospora anserina. Environ. Microbiol. 2014, 16, 141-161. [CrossRef] [PubMed]

25. Bourdais, A.; Bidard, F.; Zickler, D.; Berteaux-Lecellier, V.; Silar, P.; Espagne, E. Wood Utilization Is Dependent on Catalase Activities in the Filamentous Fungus Podospora anserina. PLoS ONE 2012, 7, e29820. [CrossRef] [PubMed]

26. van Erven, G.; Kleijn, A.F.; Patyshakuliyeva, A.; Di Falco, M.; Tsang, A.; de Vries, R.P.; van Berkel, W.J.H.; Kabel, M.A. Evidence for ligninolytic activity of the ascomycete fungus Podospora anserina. Biotechnol. Biofuels 2020, 13, 75. [CrossRef] [PubMed]

27. Dicko, M.; Ferrari, R.; Tangthirasunun, N.; Gautier, V.; Lalanne, C.; Lamari, F.; Silar, P. Lignin Degradation and Its Use in Signaling Development by the Coprophilous Ascomycete Podospora anserina. J. Fungi 2020, 6, 278. [CrossRef]

28. Munk, L.; Sitarz, A.K.; Kalyani, D.C.; Mikkelsen, J.D.; Meyer, A.S. Can laccases catalyze bond cleavage in lignin? Biotechnol. Adv. 2015, 33, 13-24. [CrossRef]

29. Otsuka, Y.; Sonoki, T.; Ikeda, S.; Kajita, S.; Nakamura, M.; Katayama, Y. Detection and characterization of a novel extracellular fungal enzyme that catalyzes the specific and hydrolytic cleavage of lignin guaiacylglycerol beta-aryl ether linkages. Eur. J. Biochem. 2003, 270, 2353-2362. [CrossRef]

30. Whittaker, J.W. Free radical catalysis by galactose oxidase. Chem. Rev. 2003, 103, 2347-2364. [CrossRef]

31. Hammel, K.E.; Mozuch, M.D.; Jensen, K.A., Jr.; Kersten, P.J. $\mathrm{H}_{2} \mathrm{O}_{2}$ recycling during oxidation of the arylglycerol beta-aryl ether lignin structure by lignin peroxidase and glyoxal oxidase. Biochemistry 1994, 33, 13349-13354. [CrossRef] [PubMed]

32. Whittaker, M.M.; Kersten, P.J.; Nakamura, N.; Sanders-Loehr, J.; Schweizer, E.S.; Whittaker, J.W. Glyoxal oxidase from Phanerochaete chrysosporium is a new radical-copper oxidase. J. Biol. Chem. 1996, 271, 681-687. [CrossRef]

33. Takano, M.; Nakamura, M.; Yamaguchi, M. Glyoxal oxidase supplies hydrogen peroxide at hyphal tips and on hyphal wall to manganese peroxidase of white-rot fungus Phanerochaete crassa WD1694. J. Wood Sci. 2010, 56, 307-313. [CrossRef]

34. Daou, M.; Yassine, B.; Wikee, S.; Record, E.; Duprat, F.; Bertrand, E.; Faulds, C.B. Pycnoporus cinnabarinus glyoxal oxidases display differential catalytic efficiencies on 5-hydroxymethylfurfural and its oxidized derivatives. Fungal Biol. Biotechnol. 2019, 6, 4. [CrossRef]

35. Kersten, P.; Cullen, D. Copper radical oxidases and related extracellular oxidoreductases of wood-decay Agaricomycetes. Fungal Genet. Biol. 2014, 72, 124-130. [CrossRef]

36. Daou, M.; Piumi, F.; Cullen, D.; Record, E.; Faulds, C.B. Heterologous Production and Characterization of Two Glyoxal Oxidases from Pycnoporus cinnabarinus. Appl. Environ. Microbiol. 2016, 82, 4867-4875. [CrossRef] 
37. Levasseur, A.; Drula, E.; Lombard, V.; Coutinho, P.M.; Henrissat, B. Expansion of the enzymatic repertoire of the CAZy database to integrate auxiliary redox enzymes. Biotechnol. Biofuels 2013, 6, 1-14. [CrossRef]

38. Lombard, V.; Golaconda Ramulu, H.; Drula, E.; Coutinho, P.M.; Henrissat, B. The carbohydrate-active enzymes database (CAZy) in 2013. Nucleic Acids Res. 2014, 42, D490-D495. [CrossRef] [PubMed]

39. Yin, D.; Urresti, S.; Lafond, M.; Johnston, E.M.; Derikvand, F.; Ciano, L.; Berrin, J.-G.; Henrissat, B.; Walton, P.H.; Davies, G.J.; et al. Structure-function characterization reveals new catalytic diversity in the galactose oxidase and glyoxal oxidase family. Nat. Commun. 2015, 6, 10197. [CrossRef]

40. Mollerup, F.; Aumala, V.; Parikka, K.; Mathieu, Y.; Brumer, H.; Tenkanen, M.; Master, E. A family AA5_2 carbohydrate oxidase from Penicillium rubens displays functional overlap across the AA5 family. PLoS ONE 2019, 14, e0216546. [CrossRef] [PubMed]

41. Kurek, B.; Kersten, P.J. Physiological regulation of glyoxal oxidase from Phanerochaete chrysosporium by peroxidase systems. Enzyme Microb. Technol. 1995, 17, 751-756. [CrossRef]

42. Daou, M.; Farfan Soto, C.; Majira, A.; Cézard, L.; Cottyn, B.; Pion, F.; Navarro, D.; Oliveira Correia, L.; Drula, E.; Record, E.; et al. Fungal Treatment for the Valorization of Technical Soda Lignin. J. Fungi 2021, 7, 39. [CrossRef] [PubMed]

43. Sternberg, D.; Dorval, S. Cellulase production and ammonia metabolism in Trichoderma reesei on high levels of cellulose. Biotechnol. Bioeng. 1979, 21, 181-191. [CrossRef] [PubMed]

44. Sayers, E.W.; Agarwala, R.; Bolton, E.E.; Brister, J.R.; Canese, K.; Clark, K.; Connor, R.; Fiorini, N.; Funk, K.; Hefferon, T.; et al. Database resources of the National Center for Biotechnology Information. Nucleic Acids Res. 2018, 47, D23-D28. [CrossRef] [PubMed]

45. Simeng, Z.; Sacha, G.; Isabelle, H.G.; Marie-Noëlle, R. A PCR-based method to quantify fungal growth during pretreatment of lignocellulosic biomass. J. Microbiol. Methods 2015, 115, 67-70. [CrossRef]

46. Méchin, V.; Laluc, A.; Legée, F.; Cézard, L.; Denoue, D.; Barrière, Y.; Lapierre, C. Impact of the brown-midrib bm 5 mutation on maize lignins. J. Agric. Food Chem. 2014, 62, 5102-5107. [CrossRef]

47. Grigoriev, I.V.; Nikitin, R.; Haridas, S.; Kuo, A.; Ohm, R.; Otillar, R.; Riley, R.; Salamov, A.; Zhao, X.; Korzeniewski, F.; et al. MycoCosm portal: Gearing up for 1000 fungal genomes. Nucleic Acids Res. 2013, 42, D699-D704. [CrossRef]

48. Katoh, K.; Standley, D.M. A simple method to control over-alignment in the MAFFT multiple sequence alignment program. Bioinformatics 2016, 32, 1933-1942. [CrossRef]

49. Chang, J.M.; Di Tommaso, P.; Notredame, C. TCS: A new multiple sequence alignment reliability measure to estimate alignment accuracy and improve phylogenetic tree reconstruction. Mol. Biol. Evol. 2014, 31, 1625-1637. [CrossRef]

50. Capella-Gutiérrez, S.; Silla-Martínez, J.M.; Gabaldón, T. trimAl: A tool for automated alignment trimming in large-scale phylogenetic analyses. Bioinformatics 2009, 25, 1972-1973. [CrossRef]

51. Lemoine, F.; Correia, D.; Lefort, V.; Doppelt-Azeroual, O.; Mareuil, F.; Cohen-Boulakia, S.; Gascuel, O. NGPhylogeny.fr: New generation phylogenetic services for non-specialists. Nucleic Acids Res. 2019, 47, W260-W265. [CrossRef]

52. Guindon, S.; Gascuel, O. A simple, fast, and accurate algorithm to estimate large phylogenies by maximum likelihood. Syst. Biol. 2003, 52, 696-704. [CrossRef]

53. Letunic, I.; Bork, P. Interactive Tree Of Life (iTOL): An online tool for phylogenetic tree display and annotation. Bioinformatics 2007, 23, 127-128. [CrossRef] [PubMed]

54. Lu, S.; Wang, J.; Chitsaz, F.; Derbyshire, M.K.; Geer, R.C.; Gonzales, N.R.; Gwadz, M.; Hurwitz, D.I.; Marchler, G.H.; Song, J.S.; et al. CDD/SPARCLE: The conserved domain database in 2020. Nucleic Acids Res. 2020, 48, D265-D268. [CrossRef] [PubMed]

55. Kelley, L.A.; Mezulis, S.; Yates, C.M.; Wass, M.N.; Sternberg, M.J.E. The Phyre2 web portal for protein modeling, prediction and analysis. Nat. Protoc. 2015, 10, 845-858. [CrossRef] [PubMed]

56. Martinez, D.; Berka, R.M.; Henrissat, B.; Saloheimo, M.; Arvas, M.; Baker, S.E.; Chapman, J.; Chertkov, O.; Coutinho, P.M.; Cullen, D.; et al. Genome sequencing and analysis of the biomass-degrading fungus Trichoderma reesei (syn. Hypocrea jecorina). Nat. Biotechnol. 2008, 26, 553-560. [CrossRef] [PubMed]

57. Haon, M.; Grisel, S.; Navarro, D.; Gruet, A.; Berrin, J.-G.; Bignon, C. Recombinant protein production facility for fungal biomass-degrading enzymes using the yeast Pichia pastoris. Front. Microbiol. 2015, 6, 1002. [CrossRef] [PubMed]

58. Kersten, P.J. Glyoxal oxidase of Phanerochaete chrysosporium: Its characterization and activation by lignin peroxidase. Proc. Natl. Acad. Sci. USA 1990, 87, 2936-2940. [CrossRef] [PubMed]

59. Paukner, R.; Staudigl, P.; Choosri, W.; Haltrich, D.; Leitner, C. Expression, purification, and characterization of galactose oxidase of Fusarium sambucinum in E. coli. Protein Expr. Purif. 2015, 108, 73-79. [CrossRef] [PubMed]

60. Bennati-Granier, C.; Garajova, S.; Champion, C.; Grisel, S.; Haon, M.; Zhou, S.; Fanuel, M.; Ropartz, D.; Rogniaux, H.; Gimbert, I.; et al. Substrate specificity and regioselectivity of fungal AA9 lytic polysaccharide monooxygenases secreted by Podospora anserina. Biotechnol. Biofuels 2015, 8, 90. [CrossRef] [PubMed]

61. Jaufurally, A.S.; Teixeira, A.R.S.; Hollande, L.; Allais, F.; Ducrot, P.-H. Optimization of the Laccase-Catalyzed Synthesis of ( \pm -Syringaresinol and Study of its Thermal and Antiradical Activities. ChemistrySelect 2016, 1, 5165-5171. [CrossRef]

62. Flourat, A.L.; Peru, A.A.M.; Haudrechy, A.; Renault, J.-H.; Allais, F. First Total Synthesis of ( $\beta-5)-(\beta-O-4)$ Dihydroxytrimer and Dihydrotrimer of Coniferyl Alcohol (G): Advanced Lignin Model Compounds. Front. Chem. 2019, 7, 5165-5171. [CrossRef] [PubMed] 
63. Liers, C.; Arnstadt, T.; Ullrich, R.; Hofrichter, M. Patterns of lignin degradation and oxidative enzyme secretion by different woodand litter-colonizing basidiomycetes and ascomycetes grown on beech-wood. FEMS MicroBiol. Ecol. 2011, 78, 91-102. [CrossRef] [PubMed]

64. Liers, C.; Ullrich, R.; Steffen, K.T.; Hatakka, A.; Hofrichter, M. Mineralization of 14C-labelled synthetic lignin and extracellular enzyme activities of the wood-colonizing ascomycetes Xylaria hypoxylon and Xylaria polymorpha. Appl. MicroBiol. Biotechnol. 2006, 69, 573-579. [CrossRef]

65. Pointing, S.B.; Parungao, M.M.; Hyde, K.D. Production of wood-decay enzymes, mass loss and lignin solubilization in wood by tropical Xylariaceae. Mycol. Res. 2003, 107 Pt 2, 231-235. [CrossRef]

66. Regalado, V.; Rodriguez, A.; Perestelo, F.; Carnicero, A.; De La Fuente, G.; Falcon, M.A. Lignin Degradation and Modification by the Soil-Inhabiting Fungus Fusarium proliferatum. Appl. Environ. Microbiol. 1997, 63, 3716. [CrossRef] [PubMed]

67. Bi, R.; Spadiut, O.; Brumer, H.; Henriksson, G. Isolation and identification of microorganisms from soil able to live on lignin as acarbon source and to produce enzymes which cleave the $\beta-0-4$ bond in a lignin model compound. Cellul. Chem Technol. 2012, $46,227-242$.

68. Bi, R.; Huang, S.; Henriksson, G. Isolation of exceedingly low oxygen consuming fungal strains able to utilize lignin as carbon source. Cellul. Chem Technol. 2016, 50, 811-817.

69. Bi, R.; Lawoko, M.; Henriksson, G. Phoma herbarum, a soil fungus able to grow on natural lignin and synthetic lignin (DHP) as sole carbon source and cause lignin degradation. J. Ind. Microbiol. Biotechnol. 2016, 43, 1175-1182. [CrossRef] [PubMed]

70. Neethu, K.; Rubeena, M.; Sajith, S.; Sreedevi, S.; Priji, P.; Unni, K.N.; Josh, M.K.S.; Jisha, V.N.; Pradeep, S.; Benjamin, S. A novel strain of Trichoderma viride shows complete lignocellulolytic activities. Adv. Biosci. Biotechnol. 2012, 3, 7. [CrossRef]

71. Bohacz, J.; Korniłłowicz-Kowalska, T. Modification of post-industrial lignin by fungal strains of the genus Trichoderma isolated from different composting stages. J. Environ. Manag. 2020, 266, 110573. [CrossRef]

72. Hammel, K.E.; Kalyanaraman, B.; Kirk, T.K. Substrate free radicals are intermediates in ligninase catalysis. Proc. Natl. Acad. Sci. USA 1986, 83, 3708. [CrossRef] [PubMed]

73. Barapatre, A.; Jha, H. Degradation of alkali lignin by two ascomycetes and free radical scavenging activity of the products. Biocatal. Biotransform. 2017, 35, 269-286. [CrossRef]

74. Bucher, V.V.C.; Pointing, S.B.; Hyde, K.D.; Reddy, C.A. Production of Wood Decay Enzymes, Loss of Mass, and Lignin Solubilization in Wood by Diverse Tropical Freshwater Fungi. Microb. Ecol. 2004, 48, 331-337. [CrossRef] [PubMed]

75. Koike, H.; Aerts, A.; LaButti, K.; Grigoriev, I.V.; Baker, S.E. Comparative Genomics Analysis of Trichoderma reesei Strains. Ind. Biotechnol. 2013, 9, 352-367. [CrossRef]

76. Jourdier, E.; Baudry, L.; Poggi-Parodi, D.; Vicq, Y.; Koszul, R.; Margeot, A.; Marbouty, M.; Bidard, F. Proximity ligation scaffolding and comparison of two Trichoderma reesei strains genomes. Biotechnol. Biofuels 2017, 10, 151. [CrossRef] [PubMed]

77. Angelova, M.B.; Pashova, S.B.; Spasova, B.K.; Vassilev, S.V.; Slokoska, L.S. Oxidative stress response of filamentous fungi induced by hydrogen peroxide and paraquat. Mycol. Res. 2005, 109, 150-158. [CrossRef]

78. Madeira, F.; Park, Y.M.; Lee, J.; Buso, N.; Gur, T.; Madhusoodanan, N.; Basutkar, P.; Tivey, A.R.N.; Potter, S.C.; Finn, R.D.; et al. The EMBL-EBI search and sequence analysis tools APIs in 2019. Nucleic Acids Res. 2019, 47, W636-W641. [CrossRef]

79. Cavener, D.R. GMC oxidoreductases: A newly defined family of homologous proteins with diverse catalytic activities. J. Mol. Biol. 1992, 223, 811-814. [CrossRef]

80. Venkatesagowda, B.; Dekker, R.F.H. Enzymatic demethylation of Kraft lignin for lignin-based phenol-formaldehyde resin applications. Biomass Convers. Biorefin. 2020, 10, 203-225. [CrossRef]

81. Mathieu, Y.; Piumi, F.; Valli, R.; Aramburu, J.C.; Ferreira, P.; Faulds, C.B.; Record, E. Activities of Secreted Aryl Alcohol Quinone Oxidoreductases from Pycnoporus cinnabarinus Provide Insights into Fungal Degradation of Plant Biomass. Appl. Environ. Microbiol. 2016, 82, 2411-2423. [CrossRef]

82. Ferreira, P.; Medina, M.; Guillén, F.; Martínez María, J.; Van Berkel Willem, J.H.; Martínez Ángel, T. Spectral and catalytic properties of aryl-alcohol oxidase, a fungal flavoenzyme acting on polyunsaturated alcohols. Biochem. J. 2005, 389, 731-738. [CrossRef] [PubMed]

83. Romero, E.; Ferreira, P.; Martínez, Á.T.; Martínez, M.J. New oxidase from Bjerkandera arthroconidial anamorph that oxidizes both phenolic and nonphenolic benzyl alcohols. Biochim. Biophys. Acta 2009, 1794, 689-697. [CrossRef] [PubMed]

84. Salvachúa, D.; Katahira, R.; Cleveland, N.S.; Khanna, P.; Resch, M.G.; Black, B.A.; Purvine, S.O.; Zink, E.M.; Prieto, A.; Martínez, M.J.; et al. Lignin depolymerization by fungal secretomes and a microbial sink. Green Chem. 2016, 18, 6046-6062. [CrossRef]

85. Miyauchi, S.; Rancon, A.; Drula, E.; Hage, H.; Chaduli, D.; Favel, A.; Grisel, S.; Henrissat, B.; Herpoël-Gimbert, I.; Ruiz-Dueñas, F.J.; et al. Integrative visual omics of the white-rot fungus Polyporus brumalis exposes the biotechnological potential of its oxidative enzymes for delignifying raw plant biomass. Biotechnol. Biofuels 2018, 11, 201. [CrossRef]

86. Challacombe, J.F.; Hesse, C.N.; Bramer, L.M.; McCue, L.A.; Lipton, M.; Purvine, S.; Nicora, C.; Gallegos-Graves, L.V.; Porras-Alfaro, A.; Kuske, C.R. Genomes and secretomes of Ascomycota fungi reveal diverse functions in plant biomass decomposition and pathogenesis. BMC Genom. 2019, 20, 976. [CrossRef]

87. Gómez-Toribio, V.; García-Martín, A.B.; Martínez, M.J.; Martínez, Á.T.; Guillén, F. Induction of Extracellular Hydroxyl Radical Production by White-Rot Fungi through Quinone Redox Cycling. Appl. Environ. Microbiol. 2009, 75, 3944. [CrossRef] 
88. Brock, B.J.; Rieble, S.; Gold, M.H. Purification and Characterization of a 1,4-Benzoquinone Reductase from the Basidiomycete Phanerochaete chrysosporium. Appl. Environ. Microbiol. 1995, 61, 3076-3081. [CrossRef]

89. Mori, T.; Koyama, G.; Kawagishi, H.; Hirai, H. Effects of Homologous Expression of 1,4-Benzoquinone Reductase and Homogentisate 1,2-Dioxygenase Genes on Wood Decay in Hyper-Lignin-Degrading Fungus Phanerochaete sordida YK-624. Curr. Microbiol. 2016, 73, 512-518. [CrossRef]

90. Berrin, J.-G.; Rosso, M.-N.; Abou Hachem, M. Fungal secretomics to probe the biological functions of lytic polysaccharide monooxygenases. Carbohydr. Res. 2017, 448, 155-160. [CrossRef]

91. Li, F.; Ma, F.; Zhao, H.; Zhang, S.; Wang, L.; Zhang, X.; Yu, H. A Lytic Polysaccharide Monooxygenase from a White-Rot Fungus Drives the Degradation of Lignin by a Versatile Peroxidase. Appl. Environ. Microbiol. 2019, 85, e02803-18. [CrossRef]

92. Ni, H.; Li, M.; Li, F.; Wang, L.; Xie, S.; Zhang, X.; Yu, H. In-situ lignin drives lytic polysaccharide monooxygenases to enhance enzymatic saccharification. Int. J. Biol. Macromol. 2020, 161, 308-314. [CrossRef] [PubMed]

93. Adav, S.S.; Ravindran, A.; Chao, L.T.; Tan, L.; Singh, S.; Sze, S.K. Proteomic Analysis of pH and Strains Dependent Protein Secretion of Trichoderma reesei. J. Proteome Res. 2011, 10, 4579-4596. [CrossRef] [PubMed]

94. Vanden Wymelenberg, A.; Sabat, G.; Mozuch, M.; Kersten, P.J.; Cullen, D.; Blanchette, R.A. Structure, organization, and transcriptional regulation of a family of copper radical oxidase genes in the lignin-degrading basidiomycete Phanerochaete chrysosporium. Appl. Environ. Microbiol. 2006, 72, 4871-4877. [CrossRef] [PubMed]

95. Manavalan, A.; Adav, S.S.; Sze, S.K. iTRAQ-based quantitative secretome analysis of Phanerochaete chrysosporium. J. Proteom. 2011, 75, 642-654. [CrossRef]

96. Adav, S.S.; Ravindran, A.; Sze, S.K. Quantitative proteomic analysis of lignocellulolytic enzymes by Phanerochaete chrysosporium on different lignocellulosic biomass. J. Proteom. 2012, 75, 1493-1504. [CrossRef]

97. Crutcher, F.K.; Moran-Diez, M.E.; Krieger, I.V.; Kenerley, C.M. Effects on hyphal morphology and development by the putative copper radical oxidase glx1 in Trichoderma virens suggest a novel role as a cell wall associated enzyme. Fungal Genet. Biol. 2019, 131, 103245. [CrossRef]

98. Oide, S.; Tanaka, Y.; Watanabe, A.; Inui, M. Carbohydrate-binding property of a cell wall integrity and stress response component (WSC) domain of an alcohol oxidase from the rice blast pathogen Pyricularia oryzae. Enzyme Microb. Technol. 2019, 125, 13-20. [CrossRef]

99. Tong, S.-M.; Chen, Y.; Zhu, J.; Ying, S.-H.; Feng, M.-G. Subcellular localization of five singular WSC domain-containing proteins and their roles in Beauveria bassiana responses to stress cues and metal ions. Environ. MicroBiol. Rep. 2016, 8, 295-304. [CrossRef]

100. Ito, N.; Phillips, S.E.; Yadav, K.D.; Knowles, P.F. Crystal structure of a free radical enzyme, galactose oxidase. J. Mol. Biol. 1994, 238, 794-814. [CrossRef]

101. Mathieu, Y.; Offen, W.A.; Forget, S.M.; Ciano, L.; Viborg, A.H.; Blagova, E.; Henrissat, B.; Walton, P.H.; Davies, G.J.; Brumer, H. Discovery of a Fungal Copper Radical Oxidase with High Catalytic Efficiency toward 5-Hydroxymethylfurfural and Benzyl Alcohols for Bioprocessing. ACS Catal. 2020, 10, 3042-3058. [CrossRef]

102. Gupta, R.; Jung, E.; Brunak, S. Prediction of N-glycosylation sites in human proteins. In Proceedings of the Pacific Symposium on Biocomputing 2004, Big Island, HI, USA, 6-10 January 2004; Volume 46, pp. 203-206.

103. Steentoft, C.; Vakhrushev, S.Y.; Joshi, H.J.; Kong, Y.; Vester-Christensen, M.B.; Schjoldager, K.T.; Lavrsen, K.; Dabelsteen, S.; Pedersen, N.B.; Marcos-Silva, L.; et al. Precision mapping of the human O-GalNAc glycoproteome through SimpleCell technology. EMBO J. 2013, 32, 1478-1488. [CrossRef]

104. Baron, A.J.; Stevens, C.; Wilmot, C.; Seneviratne, K.D.; Blakeley, V.; Dooley, D.M.; Phillips, S.E.; Knowles, P.F.; McPherson, M.J. Structure and mechanism of galactose oxidase. The free radical site. J. Biol. Chem. 1994, 269, 25095-25105. [CrossRef]

105. Andberg, M.; Mollerup, F.; Parikka, K.; Koutaniemi, S.; Boer, H.; Juvonen, M.; Master, E.; Tenkanen, M.; Kruus, K. A Novel Colletotrichum graminicola Raffinose Oxidase in the AA5 Family. Appl. Environ. Microbiol. 2017, 83, e01383-17. [CrossRef] [PubMed]

106. Xu, F.; Golightly, E.J.; Schneider, P.; Berka, R.M.; Brown, K.M.; Johnstone, J.A.; Baker, D.H.; Fuglsang, C.C.; Brown, S.H.; Svendsen, A.; et al. Expression and characterization of a recombinant Fusarium spp. galactose oxidase. Appl. Biochem. Biotechnol. 2000, 88, 23. [CrossRef]

107. Szabó, E.E.; Adányi, N.; Váradi, M. Application of biosensor for monitoring galactose content. Biosens. Bioelectron. 1996, 11, 1051-1058. [CrossRef]

108. Schumacher, D.; Vogel, J.; Lerche, U. Construction and applications of an enzyme electrode for determination of galactose and galactose-containing saccharides. Biosens. Bioelectron. 1994, 9, 85-89. [CrossRef]

109. Knowles, P.F.; Brown, R.D.; Koenig, S.H.; Wang, S.; Scott, R.A.; McGuirl, M.A.; Brown, D.E.; Dooley, D.M. Spectroscopic Studies of the Active Site of Galactose Oxidase. Inorg. Chem. 1995, 34, 3895-3902. [CrossRef]

110. Ribeaucourt, D.; Bissaro, B.; Guallar, V.; Yemloul, M.; Haon, M.; Grisel, S.; Alphand, V.; Brumer, H.; Lambert, F.; Berrin, J.-G.; et al. Comprehensive Insights into the Production of Long Chain Aliphatic Aldehydes Using a Copper-Radical Alcohol Oxidase as Biocatalyst. ACS Sustain. Chem. Eng. 2021, 9, 4411-4421. [CrossRef]

111. Towne, V.; Will, M.; Oswald, B.; Zhao, Q. Complexities in horseradish peroxidase-catalyzed oxidation of dihydroxyphenoxazine derivatives: Appropriate ranges for $\mathrm{pH}$ values and hydrogen peroxide concentrations in quantitative analysis. Anal. Biochem. 2004, 334, 290-296. [CrossRef] [PubMed] 
112. Mollerup, F.; Parikka, K.; Vuong, T.V.; Tenkanen, M.; Master, E. Influence of a family 29 carbohydrate binding module on the activity of galactose oxidase from Fusarium graminearum. Biochim. Biophys. Acta Gen. Subj. 2016, 1860, 354-362. [CrossRef]

113. Rogers, M.S.; Baron, A.J.; McPherson, M.J.; Knowles, P.F.; Dooley, D.M. Galactose oxidase pro-sequence cleavage and cofactor assembly are self-processing reactions. J. Am. Chem. Soc. 2000, 122, 990-991. [CrossRef]

114. Rogers, M.S.; Tyler, E.M.; Akyumani, N.; Kurtis, C.R.; Spooner, R.K.; Deacon, S.E.; Tamber, S.; Firbank, S.J.; Mahmoud, K.; Knowles, P.F.; et al. The stacking tryptophan of galactose oxidase: A second coordination sphere residue that has profound effects on tyrosyl radical behavior and enzyme catalysis. Biochemistry 2007, 46, 4606-4618. [CrossRef]

115. Wohlschlager, L.; Csarman, F.; Zrilić, M.; Seiboth, B.; Ludwig, R. Comparative characterization of glyoxal oxidase from Phanerochaete chrysosporium expressed at high levels in Pichia pastoris and Trichoderma reesei. Enzyme Microb. Technol. 2021, 145, 109748. [CrossRef] [PubMed]

116. Leonowicz, A.; Rogalski, J.; Jaszek, M.; Luterek, J.; Wojtas-Wasilewska, M.; Malarczyk, E.; Ginalska, G.; Fink-Boots, M.; Cho, N.-S. Cooperation of Fungal Laccase and Glucose 1-Oxidase in Transformation of Björkman Lignin and Some Phenolic Compounds. Holzforschung 1999, 53, 376-380. [CrossRef]

117. Marzullo, L.; Cannio, R.; Giardina, P.; Santini, M.T.; Sannia, G. Veratryl Alcohol Oxidase from Pleurotus ostreatus Participates in Lignin Biodegradation and Prevents Polymerization of Laccase-oxidized Substrates (*). J. Biol. Chem. 1995, $270,3823-3827$. [CrossRef] [PubMed]

118. Huang, F.; Fang, J.; Lu, X.; Gao, P.; Chen, J. Synergistic effects of cellobiose dehydrogenase and manganese-dependent peroxidases during lignin degradation. Chin. Sci. Bull. 2001, 46, 1956-1961. [CrossRef]

119. Ai, M.-Q.; Wang, F.-F.; Zhang, Y.-Z.; Huang, F. Purification of pyranose oxidase from the white rot fungus Irpex lacteus and its cooperation with laccase in lignin degradation. Process. Biochem. 2014, 49, 2191-2198. [CrossRef]

120. Majeke, B.M.; Collard, F.X.; Tyhoda, L.; Görgens, J.F. The synergistic application of quinone reductase and lignin peroxidase for the deconstruction of industrial (technical) lignins and analysis of the degraded lignin products. Bioresour. Technol. 2021, 319, 124152. [CrossRef]

121. Jeon, J.-R.; Kim, E.-J.; Murugesan, K.; Park, H.-K.; Kim, Y.-M.; Kwon, J.-H.; Kim, W.-G.; Lee, J.-Y.; Chang, Y.-S. Laccase-catalysed polymeric dye synthesis from plant-derived phenols for potential application in hair dyeing: Enzymatic colourations driven by homo- or hetero-polymer synthesis. Microb. Biotechnol. 2010, 3, 324-335. [CrossRef]

122. Kim, S.; Lee, H.; Kim, J.; Oliveira, F.; Souto, P.; Kim, H.; Nakamatsu, J. Laccase-mediated grafting of polyphenols onto cationized cotton fibers to impart UV protection and antioxidant activities. J. Appl. Polym. Sci. 2018, 135, 45801. [CrossRef]

123. Zhang, A.; Meng, X.; Bao, C.; Zhang, Q. In situ synthesis of protein-loaded hydrogels via biocatalytic ATRP. Polym. Chem. 2020, 11, 1525-1532. [CrossRef] 